\title{
The contribution of targeted therapy to the neoadjuvant chemoradiation of rectal cancer
}

\author{
Francesco Torino $^{\mathrm{a}}$, Roberta Sarmiento ${ }^{\mathrm{b}}$, Giampietro Gasparini ${ }^{\mathrm{b}, *}$ \\ ${ }^{a}$ Department of Systems Medicine - Chair of Medical Oncology, Tor Vergata University of Rome, Italy \\ b Oncologia Medica Ospedale S. Filippo Neri, Roma, Italy
}

Accepted 13 February 2013

\section{Contents}

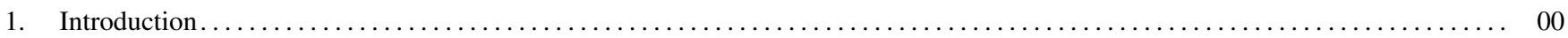

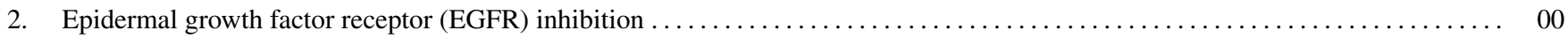

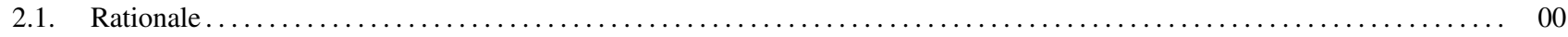

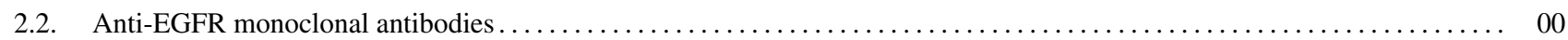

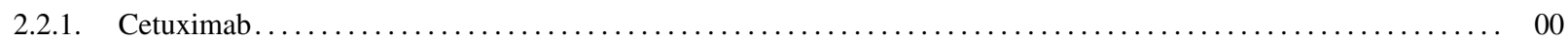

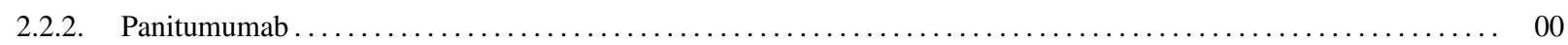

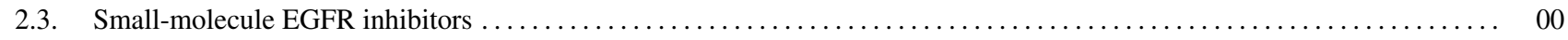

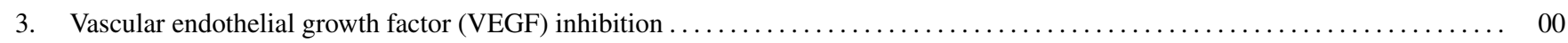

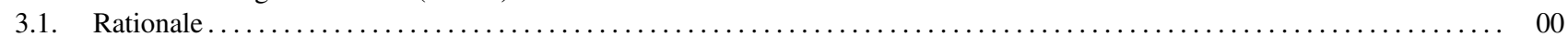

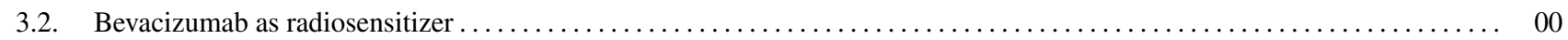

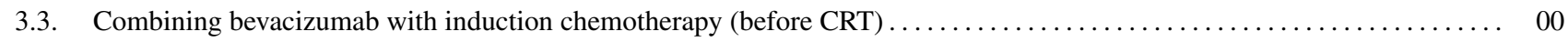

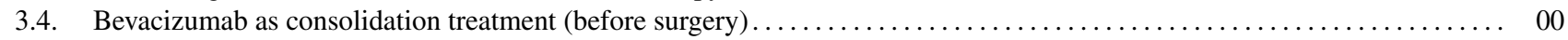

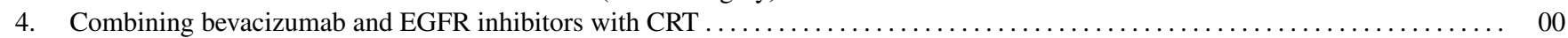

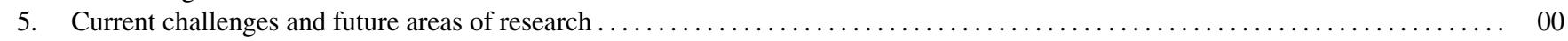

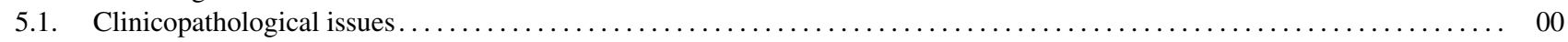

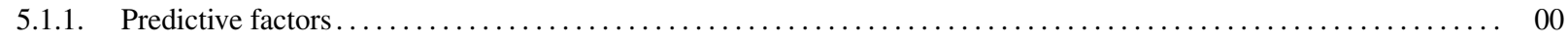

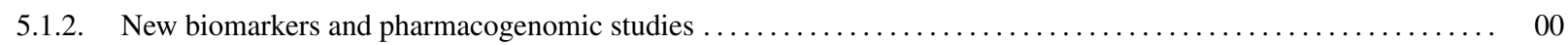

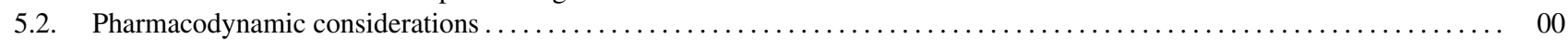

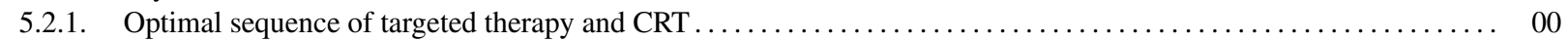

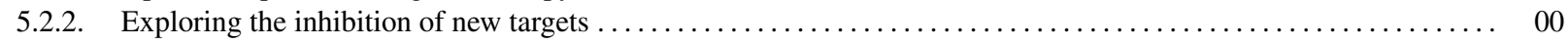

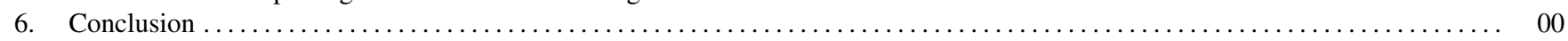

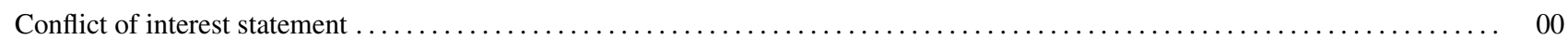

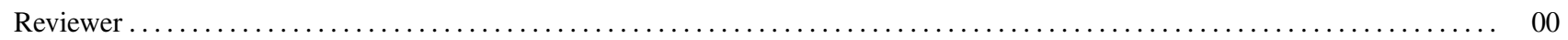

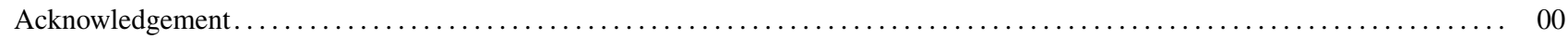

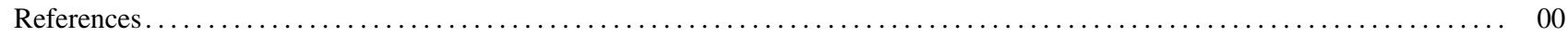

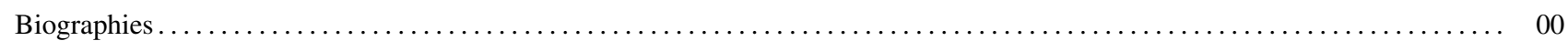

\begin{abstract}
Neoadjuvant chemoradiation therapy is a commonly used option aimed to make less aggressive surgery approaches and to improve quality of life allowing a high proportion of patients operated with sphincter-sparing surgical techniques in locally advanced rectal cancer (LARC). During the last 5 years a number of studies have tested the efficacy of more intensive chemotherapeutic approaches by combining irinotecan
\end{abstract}

\footnotetext{
* Corresponding author at: Unità Operativa Complessa di Oncologia Medica, Azienda Complesso Ospedaliero di Rilevanza Nazionale "S. Filippo Neri", Via G. Martinotti, 20 - 00135 Rome, Italy. Tel.: +39 06 33062237; fax: +39 0633062445.

E-mail address: gasparini.oncology@ hotmail.it (G. Gasparini).
} 
or oxaliplatin with fluoropyrimidines and standard radiation treatments as well as testing combined treatments with targeted agents directed against epidermal growth factor receptor (EGFR) or angiogenesis. Herein, we review the results and critiques of the published studies based on the introduction of novel targeted agents in neoadjuvant therapy of LARC.

(C) 2013 Published by Elsevier Ireland Ltd.

Keywords: Targeted therapy; Bevacizumab; Cetuximab; Rectal cancer; Neoadjuvant-treatment

\section{Introduction}

Colorectal cancer is the second leading cause of cancer worldwide and approximately one-third rises in the rectum. By SEER data, at the time of diagnosis $36 \%$ of patients affected by rectal cancer presents stage III disease [1]. Surgery remains the cornerstone in the treatment of rectal cancer and improvements in outcome are related to more radical surgical techniques, namely total mesorectal excision (TME). However, locally advanced rectal tumors (LARC) cannot be cured by using surgery alone. Randomized clinical trials demonstrated that infusional 5-fluorouracil (5FU) concomitant to preoperative radiation reduces local recurrence compared with preoperative radiation therapy (RT) [2,3] or adjuvant chemoradiotherapy (CRT) alone [4]. In comparison with preoperative radiation alone, fluorouracil-based preoperative CRT also results in downstaging/downsizing of the primary tumor mass in a large proportion of patients, obtaining in 10-25\% of surgical specimens a pathologic complete response (pCR) [5]. In turn, this may facilitate radical resection of large advanced tumors and allows sphincterpreserving surgery in patients with distal tumors. Therefore, fluorouracil-based preoperative CRT is a standard option for LARC. However, despite these progresses, approximately $50 \%$ of patients with LARC eventually die of their disease.

Since newer cytotoxic agents such as capecitabine, oxaliplatin, irinotecan, as well as the targeted agents (TAs) bevacizumab, cetuximab and panitumumab demonstrated to improve clinical outcomes in patients with metastatic colorectal cancer (mCRC), several studies have been performed to incorporate these agents for therapy of LARC.

In this review we discuss the rationale of using TAs in combination with chemoradiation therapy and the evidence emerging from the published clinical studies where these agents have been used as part of neoadjuvant treatment of patients with LARC. Furthermore the challenges and some key issues for the future development of targeted drugs in rectal cancer are discussed.

\section{Epidermal growth factor receptor (EGFR) inhibition}

\subsection{Rationale}

EGFR signaling is linked to increased proliferation, angiogenesis and metastasis in response to exogenous stress via interaction with DNA damage repair and inhibition of apoptosis. EGFR tyrosine kinase activity is increased in human cancer cells in response to irradiation and the addition of exogenous EGF makes cells resistant to radiation treatment in vitro [6]. Bonner et al. demonstrated that cetuximab, an anti-EGFR monoclonal antibody, can be safely administered with conventional or hyperfractionated radiation therapy in patients affected by head and neck cancer with improved survival [7].

EGFR is overexpressed in 50-70\% of primary rectal cancers [8] and it is related to decreased pCR, disease free survival (DFS) and overall survival (OS) $[9,10]$.

\subsection{Anti-EGFR monoclonal antibodies}

Cetuximab and panitumumab are the two approved monoclonal antibodies that bind to EGFR (anti-EGFR moAb) with high specificity, blocking ligand-induced phosphorylation of the receptor: they have been shown to lead to longer progression free survival (PFS) and OS times for patients affected by $\mathrm{mCRC}$ who failed previous therapies [11-14]. It has been demonstrated, howewer, that in advanced colon cancer the benefit is limited to those patients with wild-type KRAS tumors. The discovery of KRAS mutations as a negative predictive marker for this class of agent in $\mathrm{mCRC}$ has rapidly been integrated into clinical practice $[15,16]$.

\subsubsection{Cetuximab}

Cetuximab can be safely administered with conventional or hyperfractionated RT in patients with head and neck cancer with improved survival [7]. Based on the positive data in mCRC and synergy with RT in preclinical models there is a strong rationale to combine anti-EGFR moAb with neoadjuvant CRT in LARC (Table 1).

In an Italian Phase II study cetuximab and 5FU $\left(225 \mathrm{mg} / \mathrm{m}^{2} /\right.$ day as continuous infusion) with RT $(50.4 \mathrm{~Gy}$ in 25-28 fractions) were administered to 40 patients, with pCR in 3 patients (8\%) [17]. In a Belgian Phase I/II study, Machiels et al. [18] tested the safety and efficacy of combining preoperative RT with capecitabine $\left(650\right.$ and $825 \mathrm{mg} / \mathrm{m}^{2}$ twice daily, continuously for the duration of RT ( $45 \mathrm{~Gy}$ in 25 fractions) and cetuximab. No unexpected toxicity was found (Table 2), but only 2 of 37 patients (5\%) achieved a pCR and a total of $25 / 37$ patients $(68 \%$ ) had only moderate or minimal tumor regression.

Velenik et al. [19] treated 37 patients with cetuximab added to capecitabine $\left(825 \mathrm{mg} / \mathrm{m}^{2}\right.$ twice daily) continuously during RT (45 Gy in 25 fractions), with a pCR in $3(8 \%)$ patients. 
Table 1

Activity reported in phase I-II trials that evaluated the addition of targeted agents to preoperative chemoradiotherapy and/or to induction chemotherapy in LARC.

\begin{tabular}{|c|c|c|c|}
\hline Authors & Phase & N. of pts & Treatment schedule \\
\hline \multicolumn{4}{|c|}{ Cetuximab/panitumumab/EGFR-TKI } \\
\hline Bertolini et al. 2009 & II & 40 & Cetuximab followed by FU/RT $50.4 \mathrm{~Gy}$ \\
\hline Machiels et al. 2007 & $\mathrm{I} / \mathrm{II}$ & 40 & Cetuximab + capecitabine + RT45 Gy \\
\hline
\end{tabular}
$\mathrm{pCR} \%$

Velenik et al. 2010

Rodel et al. 2008

$\begin{array}{ll}\text { II } & 37 \\ \text { I/II } & 48\end{array}$

Cetuximab + cape + RT45 Gy

Cetuximab + cape + RT 50.4 Gy

8

Mc Collum et al. 2010

$\begin{array}{lr}\text { IIb } & 133 \\ \text { II } & 40 \\ \text { II } & 50\end{array}$

2009

Dewdney et al. $2012 \quad$ IIb $\quad 164$

Pinto et al. 2011

Valentini et al. 2008

II $\quad 60$

Bevacizumab as radiosensitizer

Willett et al. 2009

I-II

41

32

Crane et al. 2010

II

25

Velenik et al. 2011

II

61

Spiegel et al. 2011

II

35

Bevacizumab $(5 \mathrm{mg} / \mathrm{kg})$ on days 1 and 15

(cohort A), or every 2 weeks (cohort B), 5FU

$\left(225 \mathrm{mg} / \mathrm{m}^{2} /\right.$ day on days $\left.1-42\right)$, RT 50.4 Gy

(1.8 Gy/day or 28 fractions)

Kennecke et al. $2011 \quad$ II $\quad 42 \quad$ Bevacizumab $(5 \mathrm{mg} / \mathrm{kg}$, days $-14,1,15,29)$ capecitabine $\left(825 \mathrm{mg} / \mathrm{m}^{2}\right.$ twice daily days $1-14$ and 22-35) + oxaliplatin $\left(50 \mathrm{mg} / \mathrm{m}^{2}\right.$ on days 1,8 , 22, 29); RT 50.4 Gy (28 fractions including

\section{boost)}

Resh et al. 2012

II

$8^{\mathrm{a}}$

Bevacizumab (5 mg/kg, days 1, 15, 29): capecitabine $\left(825 \mathrm{mg} / \mathrm{m}^{2}\right.$ twice daily on RT-days weeks 1-4); RT 45 Gy (1.8 Gy/day in 5 weeks)

Gasparini et al. $2012 \quad$ II

43

Bevacizumab $(5 \mathrm{mg} / \mathrm{kg}$ every 2 weeks for 4 cycles: days $-14,1,15,29$ ); capecitabine $\left(825 \mathrm{mg} / \mathrm{m}^{2}\right.$ twice a day for 5.5 weeks $)$; RT 50.4 Gy (28 fractions over 5.5 weeks)

Martinez-Villacampa IIb et al. 2012
IIb $\quad 90$

12

5

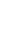

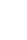


Table 1 (Continued)

\begin{tabular}{|c|c|c|c|c|c|}
\hline Authors & Phase & N. of pts & Treatment schedule & $\mathrm{pCR} \%$ & \\
\hline \multicolumn{6}{|c|}{ Bevacizumab in combination with induction chemotherapy } \\
\hline Dipetrillo et al. 2010 & II & 25 & $\begin{array}{l}\text { Bevacizumab }(5 \mathrm{mg} / \mathrm{kg} \text {, days } 1,15, \\
29):+\mathrm{mFOLFOX6}(1 \mathrm{month}) \rightarrow \text { bevacizumab } \\
(5 \mathrm{mg} / \mathrm{kg}, \text { days } 1,15,29)+5 \mathrm{FU} \\
\left(200 \mathrm{mg} / \mathrm{m}^{2} / \text { day }\right) \text { and oxaliplatin } \\
\left(50-40 \mathrm{mg} / \mathrm{m}^{2} / \text { week }+ \text { RT } 50.4 \mathrm{~Gy}(1.8 \mathrm{~Gy} / \text { day, } 5\right. \\
\text { days/week or } 25 \text { fractions })\end{array}$ & 20 & $\begin{array}{l}\text { No evidence of malignancy } \\
\text { on the specimen }\end{array}$ \\
\hline Noguè et al. 2011 & II & 47 & $\begin{array}{l}\text { Bevacizumab }(7.5 \mathrm{mg} / \mathrm{kg})+\text { XELOX } \\
\text { (capecitabine }+ \text { oxaliplatin) for } 4 \\
\text { cycles } \rightarrow \text { bevacizumab }(5 \mathrm{mg} / \mathrm{kg} \text { every } 2 \\
\text { weeks) + capecitabine }\left(825 \mathrm{mg} / \mathrm{m}^{2} \text { twice daily }\right. \\
\text { on days } 1-15) \\
\text { RT }(50.4 \text { Gy ( } 28 \text { fractions including boost) }\end{array}$ & 36 & $\begin{array}{l}\text { yPT0,yN0, assessed using the } \\
\text { Dworak scale }\end{array}$ \\
\hline \multicolumn{6}{|c|}{ Bevacizumab in combination with chemotherapy only, with CRT and as consolidation therapy (before surgery) } \\
\hline Schrag et al. 2011 & II & 31 & $\begin{array}{l}\text { Bevacizumab (dose not reported; cycles } 1-4 \text { ) } \\
\text { FOLFOX } 6 \text { cycles } \\
\text { No radiation therapy }\end{array}$ & 27 & Not reported in the abstract. \\
\hline Liang et al. 2011 & II & 28 & $\begin{array}{l}\text { Bevacizumab }(5 \mathrm{mg} / \mathrm{Kg}) \text { biweekly }+ \text { FOLFOX } \\
\text { for } 6 \text { cycles during and after CRT } \\
\text { RT } 45 \text { Gy ( } 25 \text { fractions } 33 \text { days })\end{array}$ & 25 & $\begin{array}{l}\text { Histopathologic examination } \\
\text { of the resected tumor } \\
\text { according to TRG }\end{array}$ \\
\hline
\end{tabular}

CRT, chemoradiotherapy; EGFR-TKI, epidermal growth factor receptor tyrosine kinase inhibitor; pCR, pathologic complete response; RT, radiotherapy.

a Accrual terminated because of grade 3 or 4 toxicities in $\geq 50 \%$ of patients at a programmed interim analysis.

The association of cetuximab with capecitabine $\left(825 \mathrm{mg} / \mathrm{m}^{2}\right.$ twice daily, days $1-14$ and $\left.22-35\right)$, oxaliplatin (50 mg/m $\mathrm{m}^{2}$, days $1,8,22$ and 29), and RT (50.4 Gy in 28 fractions) was also evaluated in 48 patients, with a pCR reached in $4(9 \%)$ patients [20].

Preliminary results of a randomized phase II study evaluating continuous infusion of 5FU and RT, with or without cetuximab, have been recently reported: pCR was obtained in $33 \%$ and $31 \%$ of patients, respectively [21].

Two phase II trials evaluated the addition of cetuximab to capecitabine-irinotecan and RT. In the first study cetuximab was added to capecitabine $\left(825 \mathrm{mg} / \mathrm{m}^{2}\right.$ twice daily, 5 days a week), irinotecan $\left(40 \mathrm{mg} / \mathrm{m}^{2}\right.$, days $1,8,15,22$ and 29), and RT (50.4 Gy in 28 fractions) in 10 patients, with pCR obtained in $2(20 \%)$ patients [22]. In the MARGIT study, 50 patients received cetuximab in combination with capecitabine $\left(500 \mathrm{mg} / \mathrm{m}^{2}\right.$ twice daily continuously), irinotecan ( $40 \mathrm{mg} / \mathrm{m}^{2}$ weekly), and RT (50.4 Gy in 28 fractions), with a pCR in $4(8 \%)$ patients [23].

A large multinational randomized phase II study (the EXPERT-C study) compared neoadjuvant therapy with oxaliplatin, capecitabine, and CRT with or without cetuximab in 164 patients [24]. Patients with magnetic resonance imaging (MRI)-defined high risk rectal cancer received four cycles of capecitabine-oxaliplatin (CAPOX) followed by capecitabine chemoradiotherapy, surgery and adjuvant CAPOX (four cycles) or the same regimen plus weekly cetuximab $($ CAPOX + C). Ninety $(60 \%)$ of the 149 assessable tumors were K-RAS or BRAF wild-type and in these patients the addition of cetuximab did not improve $\mathrm{pCR}$, the primary end point (9\% versus $11 \%$, respectively; $p=1.0$, HR 1.22 ) or PFS (HR 0.65, $p=0.363$ ). However, cetuximab significantly improved response rate $(\mathrm{CAPOX}$ versus $\mathrm{CAPOX}+\mathrm{C}$ : after chemotherapy, $51 \%$ versus $71 \%$, respectively; $p=0.038)$ and OS (HR 0.27, $p=.034)$ [24].

\subsubsection{Panitumumab}

The efficacy of panitumumab combined to 5FU, oxaliplatin and RT was investigated as neoadjuvant treatment in high-risk LARC patients by Pinto et al. [25] (Table 1). Panitumumab at the dose of $6 \mathrm{mg} / \mathrm{kg}$ i.v. was administered 2 weeks before the start of CRT and after, in combination with CRT every 2 weeks, for a total of 3 times. $5 F U\left(225 \mathrm{mg} / \mathrm{m}^{2} /\right.$ day in continuous infusion) and oxaliplatin $\left(60 \mathrm{mg} / \mathrm{m}^{2}\right.$ i.v. weekly for 6 courses) were given concurrently with RT (50.4 Gy delivered in 28 daily fractions of $1.8 \mathrm{~Gy}$, on 5 consecutive days per week). Adjuvant chemotherapy with FOLFOX-4 regimen in combination with panitumumab for 8 cycles was planned after surgical treatment. The primary end-point of the study was pCR rate. All the 60 patients enrolled in 11 Italian centers were evaluable for safety, 57 for response; $55(91.7 \%)$ patients underwent surgery and were assessable for pCR. A pCR rate of 21.1 (95\% confidence interval: 10.4-31.6\%) was obtained. Regarding the safety profile, the panitumumab combination treatment was associated with high incidence of grade 3-4 diarrhea that reached 38.9\% (Table 2).

In the starPan (STAR-02) study, the primary end point was not reached, with a pCR rate of $21.1 \%$, however, the addition of panitumumab to 5FU-oxaliplatin CRT showed a higher pCR rate as compared to the results of the phase II studies based on cetuximab-fluoropyrimidine combination with or without oxaliplatin. A possible explanation for the different results in terms of higher pCR of StarPan study may be related to different chemotherapy schedules: in this study 5FU was administered as continuous infusion and oxaliplatin weekly for 6 times. Moreover, in the StarPan study, the presence of 
Table 2

Toxicity reported in phase I-II trials that evaluated the addition of targeted agents to preoperative chemoradiotherapy and/or to induction chemotherapy in LARC.

Authors Phase

Bertolini et al. 2009

II

Machiels et al. 2007

I/II

40

II

37

I/II

48

Rodel et al. 2008

$\begin{array}{lccl}\text { Velenik et al. } 2010 & \text { II } & 37 & \text { Cetuximab + cape + RT45 } \\ & & & \text { Gy } \\ \text { Rodel et al. } 2008 & \text { I/II } & 48 & \text { Cetuximab + cape + RT } \\ & & & 50.4 \mathrm{~Gy}\end{array}$

Mc Collum et al. 2010

Kim et al. 2011
IIb

II
133

40

$-40$

Cetuximab + capecitabine + RT45 Gy
Cetuximab followed

by FU/RT 50.4 Gy
5 FU/RT 45 Gy (arm

A) with cetuximab

(arm B)

Cape + iri + cetuximab + RT 50.4 Gy
Horisberger et al. 2009
II $\quad 50$
Cetuximab + cape + iri + RT 50.4 Gy
Toxicity

Skin rash G1/2 70\%, G3/4 7.5\%; hypersensitivity reactions $\mathrm{G} 1 / 213 \%, \mathrm{G} 3 / 47.5 \%$; gastrointestinal toxicity G1/2 47\%, G3/4 13\%; diarrhea G1/2 32\%, G3/4 $5 \%$; stomatitis G1/2 2.5\%, G3/4 2.5\%; nausea/vomiting $\mathrm{G} 1 / 20 \%, \mathrm{G} 3 / 40 \%$; haematologic toxicity G1/2 2.5\%, G3/4 2.5\%; anemia G1/2 2.5\%, G3/4 0\%; trombocytopenia $\mathrm{G} 1 / 2$ and $\mathrm{G} 3 / 40 \%$; neutropenia $\mathrm{G} 1 / 2$ and G3/4 0\%; febrile neutropenia G1/2 0\%, G3/4 2.5\%; systemic symptoms G1/2 5\%, G3/4 0\%; fatigue G1/2 $5 \%, \mathrm{G} 3 / 40 \%$; urologic toxicity G1/2 2.5\%, G3/4 0\%; cystitis G1/2 2.5\%; G3/4 0\%

G1/2 acneiform rash: $87 \%$, diarrhea: $65 \%$, fatigue: $57 \%$; 2 pts with G3 dhiarrea followed by ileitis and occlusive syndrome discontinuated RT; 1 pt had G3 allergic reaction to cetuximab; G4 were reported by 3 pts (one myocardial infarction during CT-RT; one pulmonary embuslim, one fatal pulmonary infection with sepsis) G1/2 acneiform rash: $86 \%$; G3 radiodermatitis: $16 \%$; G3 dhiarrea: 11\%; G3 hypersensitivity: 5\%

Phase I: G3 hypersensitivity: 14\%; G3 diarrhea: 14\% Phase II: Leukopenia G1/2 17\%, G3 2\%, G4/5 1\%a; thrombocytopenia $10 \%$, G3 1\%, G4/5 1\% ; anemia G1/2 18\%; diarrhea G1/2 27\%, G3 8\%, G4/5 1\% nausea/vomiting G1/2 16\%, G $32 \%$, fatigue G1/2 6\%, stomatitis G1 3\%, constipation/ileus G1/2 1\%, G3 1\% proctitis $\mathrm{G} 1 / 27 \%$, G3 1\%; sensory neuropathy G1/2 $11 \%$, G3 3\%; hand-foot syndrome G1/2 8\%; radiation dermatitis G1/2 20\%, G3 4\%; acneiform rash G1/2 $45 \%,{ }^{\text {a }} \mathrm{G} 32 \%$; cardiac toxicity G1/2 1\%, G3 1\%; hyperbilirubinemia G1/2 8\%; transaminases (GPT, GOT) G1/2 25\%, G3 3\%; alkaline phosphatase G1/2 $13 \%$; hypocalcemia/hyperkalemia G4/5 $1 \%^{\mathrm{a}}$; allergic reaction/hypersensitivity G1/2 5\%, G3 1\%,

infection/fever G1/2 10\%, G3 3\%, G4/5 1 (death from multiorgan failure due to dihydropyrimidine dehydrogenase deficiency); ${ }^{\mathrm{a}}$ acneiform rash, G1 in 32 pts $(68 \%)$ and $\mathrm{G} 2$ in 13 pts $(28 \%)$

G3/4 diarrhea: 16/24\%; G3/4 rash: 0/10\%, mucositis: $5 / 5 \%$

Leukopenia G1 17.9\%, G2 30.8\%, G3 7.7\%, G 4 2.6\%; neutropenia G1 15.4\%, G2 20.5\%, G3 5.1\%, anemia G1 $10.3 \%, \mathrm{G} 25.1 \%$, G3 2.6\%. AST abnormality G1 $23.1 \%$, G2 2.6\%, ALT abnormality G1 17.9\%, G2 $10.3 \%$, fatigue G1 12.8\%, G2 5.1\%, G3 2.6\%, skin rash G1 41.0\%, G2 46.2\%, G3 2.6\%, allergic reaction G1 $5.1 \%$, G2 $10.3 \%$, alopecia G1 2.6\%, anorexia G1 43.6\%, G2 5.1\%; diarrhea G1 33.3\%, G2 12.8\%, G3 $5.1 \%$; ileus G3 2.6\%, abdominal pain G1 17.9\%, G2 $7.7 \%$, anal pain G1 10.3\%, G2 41.0\%, fever G2 2.6\%, infection G2 2.6\%, vomiting G1 2.6\%, G2 10.3\%, G3/4 19.4\%; hand-foot syndrome G1 7.7\%, G2 5.1\% Anemia G1 52\%; G3 6\% G4 2\% thrombocytopenia G1 $8 \%$; leukocytopenia G1 34\% G2 6\% G3 2\% G4 2\%; nausea/vomiting G1 40\%, G2 4\%, G3 2\%; Diarrhea G1 20\%, G2 34\%, G3 30\%, abdominal pain G1 22\%, G2 $8 \%$, G3 4\%,; proctitis G1 26\%, G2 26\%, G3 2\%, bilirubin elevation $^{\mathrm{a}} \mathrm{G} 4$ 2\%; ASAT/ALAT elevation G1 $32 \%, \mathrm{G} 28 \%$, G3 10\%, hand-foot skin reaction G1 10\%, G2 4\%, acnelike skin rash G1 36\%, G2 46\%, G3 6\%, anorexia + G1 4\%, G2-3-40\% 
Table 2 (Continued)

\begin{tabular}{|c|c|c|c|c|}
\hline Authors & Phase & N. of pts & Treatment schedule & Toxicity \\
\hline Dewdney et al. 2012 & $\mathrm{IIb}$ & 164 & $\begin{array}{l}\text { Cape }+ \text { oxa }+ \text { RT } \\
50.4 \text { Gy without } \\
\text { cetuximab (arm } \\
\text { A)/with cetuximab } \\
\text { (arm B) }\end{array}$ & $\begin{array}{l}\text { Neoadjuvant CT Arm A/Arm B: febrile neutropenia } \\
1 \% / 1 \% \text {; diarrhea } 9 \% / 8 \% \text {; lethargy } 10 \% / 10 \% \text {; nausea } \\
\text { and vomiting } 2 \% / 2 \% \text {; hand-foot syndrome } 1 \% / 4 \% \text {; } \\
\text { stomatitis } 0 \% / 1 \% \text {; neuropathy } 0 \% / 2 \% \text {; rash } 0 \% / 10 \% \text {; } \\
\text { CRT Arm A/Arm B: diarrhea } 1 \% / 10 \% \text {; rash } 0 \% / 9 \% \text {; } \\
\text { hand-foot syndrome } 1 \% / 4 \% \text {; }\end{array}$ \\
\hline Pinto et al. 2011 & II & 60 & $\begin{array}{l}\text { Panitumumab + 5FU + } \\
\text { oxa + RT } 50.4 \text { Gy }\end{array}$ & $\begin{array}{l}\text { Diarrhea G1/G2: 35.6\%, G3/G4 38.9\%, nausea G1/2: } \\
\text { 28.8\%, G3/4 5.1\%, vomiting G1/2 18.6\%, G3/4 1.7\%, } \\
\text { stomatitis G1/2 11.8\%, acneiform rash: G1/2: 59.3\%, } \\
\text { G3/4: } 18.6 \% \text {, asthenia G1/2 30.5\%, G3/4 3.4\%, } \\
\text { anorexia G1/2 22\%, G3/4 3.4\%, leucopenia G1/2 } \\
\text { 13.5\%, G3/4 1.7\%, neutropenia G1/2 8.4\%, G3/4 1.7\%, } \\
\text { anemia G1/2 10.1\%, G3/4 0; hand-foot sindrome G3/4 } \\
2 \% \text {, periheral neuropathy G1/2 13.5\%, G3/4 0\%, one } \\
\text { toxic death due to diarrhea }\end{array}$ \\
\hline Czito et al. 2006 & $16(10 \mathrm{~F}$ & RC) & $\begin{array}{l}\text { Gefitinib + cape + RT } \\
45 \text { Gy }\end{array}$ & $\begin{array}{l}\text { Toxicity in patients affected by LARC: G4 diarrhea } \\
16.6 \% \text { (DLT); G1/2 diarrhea } 33.2 \% \text {; death: } 1 \mathrm{pt}(16.6 \%) \\
\text { due to arterial thrombosis complicated aspiration } \\
\text { pneumonia }\end{array}$ \\
\hline Valentini et al. 2008 & $\mathrm{I} / \mathrm{II}$ & 41 & $\begin{array}{l}\text { Gefitinib + 5FU } \\
\text { c.i. + RT 50.4 Gy }\end{array}$ & $\begin{array}{l}\text { Diarrhea } 12.8 \% \text {, nausea/vomiting } 7.6 \% \text {; skin toxicity } \\
15.3 \% \text {; hepatic toxicity } 25.6 \% \text {; GU toxicity } 10.2 \% \text {; } \\
\text { other G3 toxicities: ( } 1 \text { cardiovascular, } 1 \\
\text { musculoskeletal, and } 1 \text { as constitutional symptoms). } \\
\text { G1/2 proctitis/tenesmus } 21.6 \% \text {; hematologic } 1 \% . \text { G1/2 } \\
\text { rectal blood spots } 17 \% \text {, metabolic/laboratory alterations } \\
17 \% \text {, neurologic disturbance } 5 \% \text {, ocular/visual } 2.4 \% \text {, } \\
\text { pain } 5 \% \text {, pulmonary } 1 \%\end{array}$ \\
\hline
\end{tabular}

\section{Bevacizumab as radiosensitizer} Willett et al. 2009 I-II II 25
Bevacizumab (5 or $10 \mathrm{mg} / \mathrm{kg}$ ) on day -14 and then every 2 weeks ( 4 cycles); $5 \mathrm{FU}$ infusion $\left(225 \mathrm{mg} / \mathrm{m}^{2} / 24 \mathrm{~h}\right)$ during cycles 2 to 4 ; RT 50.4 Gy (28 fractions over 5.5 weeks)

Bevacizumab $(5 \mathrm{mg} / \mathrm{kg})$ every 2 weeks for 3 doses; capecitabine $\left(900 \mathrm{mg} / \mathrm{m}^{2}\right.$ orally twice daily on days of radiation); RT 50.4 Gy (28 fractions, 5.5

weeks)

Bevacizumab $(5 \mathrm{mg} / \mathrm{kg})$ on day -14 and then every 2 weeks (4 cycles); capecitabine $\left(825 \mathrm{mg} / \mathrm{m}^{2}\right.$ twice daily on days 1-38); RT 50.4 Gy (1.8 Gy/day, 5 days/week for 5 weeks + three 1.8 Gy/day)
$\mathrm{G} 2 / 3$ radiation dermatitis $(n=7) ; \mathrm{G} 2 / 3$ diarrhea $(n=12)$; G2/3 hypertension $(n=4) ; \mathrm{G} 2 / 3$ proctalgia/proctitis/colitis $(n=13)$; anastostomotic leak with presacral abscess requiring drainage $(n=1)$, abscess requiring drainage $(n=1)$, pelvic hematoma $(n=1)$, delayed healing of perineal incision $(n=2)$, ileus $(n=2)$, neurogenic bladder $(n=1)$, perforated ileostomy-stent related $(n=1)$, pulmonary embolus $(n=1)$, wound infection $(n=3)$

G2 gastrointestinal $(n=3 ; 12 \%)$; G3 perianal skin $(n=1 ; 4 \%)$; G2 hand-foot syndrome $(n=6 ; 24 \%)$. Major wound complications requiring surgical intervention $(n=3 ; 12 \%)$

Dermatitis $10 \%$, proteinuria $6.5 \%$, leukopenia $5 \%$. Delayed wound healing $(n=18,30 \%)$, infection/abscess $(n=12,20 \%)$; anastomotic leakage $(n=7,11.7 \%)$. Surgical re-intervention for anastomotic leakage $(n=3)$, abdominal abscess $(n=2)$ and pneumothorax $(n=1)$ 
Table 2 (Continued)

\begin{tabular}{|c|c|c|c|c|}
\hline Authors & Phase & N. of pts & Treatment schedule & Toxicity \\
\hline Spiegel et al. 2011 & II & 35 & $\begin{array}{l}\text { Bevacizumab } \\
(5 \mathrm{mg} / \mathrm{kg}) \text { on days } 1 \\
\text { and } 15 \text { (cohort A), or } \\
\text { every } 2 \text { weeks (cohort } \\
\text { B), } 5 \mathrm{FU} \\
\left(225 \mathrm{mg} / \mathrm{m}^{2} / \text { day on }\right. \\
\text { days } 1-42), \text { RT }\end{array}$ & $\begin{array}{l}\text { G3/4 diarrhea (A cohort, 14\%; B cohort, } 29 \% \text { ), } \\
\text { neutropenia (A cohort, 14\%, B cohort, } 23 \% \text { ), mucositis } \\
\text { (A cohort, } 23 \% \text {, B cohort, } 0 \% \text { ). Bowel perforation and } \\
\text { pelvic infection (cohort A, } n=1 \text { each), bowel } \\
\text { perforation }(n=2) \text {, anal wound dehiscence }(n=1) \text {, } \\
\text { perianal infection }(n=2) \text {, and rectovaginal fistula }(n=1) \\
\text { (cohort B) }\end{array}$ \\
\hline
\end{tabular}

Kennecke et al. 2011

II

42

Resh et al. 2012

Gasparini et al. 2012

Martinez-Villacampa et al. 2012

Bevacizumab in combination with induction chemotherapy Dipetrillo et al. 2010
25
$50.4 \mathrm{~Gy}(1.8 \mathrm{~Gy} / \mathrm{day}$

or 28 fractions)

Bevacizumab

$(5 \mathrm{mg} / \mathrm{kg}$, days -14 ,

$1,15,29)$ capecitabine $\left(825 \mathrm{mg} / \mathrm{m}^{2}\right.$ twice daily days $1-14$ and 22-35) + oxaliplatin $\left(50 \mathrm{mg} / \mathrm{m}^{2}\right.$ on days 1 , $8,22,29)$; RT $50.4 \mathrm{~Gy}$ (28 fractions including boost)

Bevacizumab ( $5 \mathrm{mg} / \mathrm{kg}$, days 1,15 , 29): capecitabine $\left(825 \mathrm{mg} / \mathrm{m}^{2}\right.$ twice daily on RT-days weeks 1-4); RT 45 Gy (1.8 Gy/day in 5 weeks).

Bevacizumab ( $5 \mathrm{mg} / \mathrm{kg}$ every 2 weeks for 4 cycles: days $-14,1,15,29)$; capecitabine $\left(825 \mathrm{mg} / \mathrm{m}^{2}\right.$ twice a day for 5.5 weeks) RT 50.4 Gy (28 fractions over 5.5 weeks)

Arm A: bevacizumab ( $5 \mathrm{mg} / \mathrm{kg}$ for 3 doses) capecitabine $\left(825 \mathrm{mg} / \mathrm{m}^{2}\right.$ twice daily). Arm B:

capecitabine $\left(825 \mathrm{mg} / \mathrm{m}^{2}\right.$ twice daily) RT 45 Gy (25 fractions in 5 weeks)s

Bevacizumab

(5 mg/kg, days 1,15 , 29): + mFOLFOX6 (1 month) $\rightarrow$ bevacizumab $(5 \mathrm{mg} / \mathrm{kg}$, days 1,15 , 29) $+5 \mathrm{FU}$

(200 mg/m $/ \mathrm{m}^{2} /$ day) and oxaliplatin (50-40 mg/m²/week + RT $50.4 \mathrm{~Gy}(1.8 \mathrm{~Gy} /$ day, 5 days/week or 25 fractions)
G3/4 diarrhea 24\%; G3/4 hypertension 5\%; Rash, hand-foot syndrome $7 \%$; post-operative complications: pelvic infection ( $n=11,29 \%)$; delayed healing $(n=7$, $18 \%$; G3/4 in 3 patients, $8 \%$ ); anastomotic leak $(n=6$, $16 \%$; G3/4 in 2 pts $5 \%)$; G1/2 fistulae $(n=3,8 \%) .4$ pts $(11 \%)$ required a reintervention

G3 intestinal bleeding 25\%; G3 diarrhea 25\%; G3/4 perianal and abdominal pain $25 \%$; G3 anemia $12.5 \%$

G3 diarrhea ( $n=3$ pts, $7.14 \%$ ); neutropenia ( $n=2 \mathrm{pts})$; $\mathrm{G} 1 / 2$ hypertension $(n=3$ pts, $7.14 \%)$, G2 proteinuria ( $n=1$ patient, $2.38 \%$. One patient died due bowel perforation; two patients presented failure to anastomosis and postoperative abscess, respectively

G3/4 toxicity rates were $18 \%$ and $13 \%$ (arm A versus B, $p=0.50)$; postoperative complications were reported by $19(43 \%)$ patients in arm A compared with $17(37 \%)$ in $\operatorname{arm~B~}$

Grade 3/4 diarrhea (40\%), neutropenia (16\%), and pain (16\%). Postoperative complications: 9 pts $(36 \%)$, infection $(n=4)$, delayed healing $(n=3)$, leak/abscess $(n=2)$, sterile fluid collection $(n=2)$, ischemic colonic reservoir $(n=1)$, and fistula $(n=1)$ 
Table 2 (Continued)

\begin{tabular}{|c|c|c|c|c|}
\hline Authors & Phase & N. of pts & Treatment schedule & Toxicity \\
\hline Noguè et al. 2011 & II & 47 & $\begin{array}{l}\text { Bevacizumab } \\
(7.5 \mathrm{mg} / \mathrm{kg})+\text { XELOX } \\
\text { (capecitabine + oxaliplatin) } \\
\text { for } 4 \\
\text { cycles } \rightarrow \text { bevacizumab } \\
(5 \mathrm{mg} / \mathrm{kg} \text { every } 2 \\
\text { weeks })+ \text { capecitabine } \\
\left(825 \mathrm{mg} / \mathrm{m}^{2} \text { twice }\right. \\
\text { daily on days } 1-15) \\
\text { RT }(50.4 \text { Gy }(28 \\
\text { fractions including } \\
\text { boost })\end{array}$ & $\begin{array}{l}\text { G3/4: diarrhea } 11 \% \text {, neutropenia } 6 \% \text {. Postoperative } \\
\text { complication: } 26 \text { pts }(58 \%) \text {, wound infection }(n=10) \text {, } \\
\text { intra-abdominal infections }(n=7) \text {, anastomotic leak } \\
(n=5) \text {, stoma complications }(n=2) \text {, other complications } \\
(n=10) . \text { Re-surgery: } 11 \text { pts }(24 \%)\end{array}$ \\
\hline \multicolumn{5}{|c|}{ Bevacizumab in combination with chemotherapy only, with CRT and as consolidation therapy (before surgery) } \\
\hline Schrag et al. 2011 & II & 31 & $\begin{array}{l}\text { Bevacizumab (dose } \\
\text { not reported; cycles } \\
1-4) \\
\text { FOLFOX } 6 \text { cycles } \\
\text { No radiation therapy }\end{array}$ & $\begin{array}{l}\text { Two patients withdrawn the study due to cardiovascular } \\
\text { side-effects (angina/arrhythmia) after } 1-2 \text { cycles. One } \\
\text { patient had high output ileostomy post-operatively }\end{array}$ \\
\hline Liang et al. 2011 & II & 28 & $\begin{array}{l}\text { Bevacizumab } \\
(5 \mathrm{mg} / \mathrm{kg}) \\
\text { biweekly + FOLFOX } \\
\text { for } 6 \text { cycles during } \\
\text { and after CRT; RT } \\
45 \text { Gy ( } 25 \text { fractions } / 33 \\
\text { days) }\end{array}$ & $\begin{array}{l}\text { Postoperative complications: } 21.4 \% \text { (upper } \\
\text { gastro-intestinal bleeding, deep vein thrombosis, pelvic } \\
\text { abscess, wound infection, enterocutaneous fistula, and } \\
\text { perineal fistula). The median blood loss was } \\
\text { significantly greater than in the historic series without } \\
\text { bevacizumab therapy. One operative mortality }(3.6 \%) \\
\text { occurred }\end{array}$ \\
\hline
\end{tabular}

CRT, chemoradiotherapy; EGFR-TKI, epidermal growth factor receptor tyrosine kinase inhibitor; GI, gastrointestinal; GU, genitourinary; LARC, locally advanced rectal cancer; PC, pancreatic cancer; RT, radiotherapy.

a Accrual terminated because of grade 3 or 4 toxicities in $\geq 50 \%$ of patients at a programmed interim analysis.

K-RAS and BRAF mutations in the pre-treatment biopsy was not correlated with pCR. In fact, the predictive significance of K-RAS and BRAF mutations in patients affected by rectal cancer submitted to preoperative CRT is not well established [25].

\subsection{Small-molecule EGFR inhibitors}

Gefitinib is an orally active anillinoquinazoline that reversibly inhibits EGFR tyrosine kinase autophosphorylation and inhibits downstream signaling. Preclinical studies in human colorectal cancer and other cancer cell lines have shown enhanced cytotoxicity when gefitinib is combined with CRT [26]. Gefitinib with 5FU-based chemotherapy appears to be feasible in patients with advanced colorectal cancer without a significant increase in severity of side effects $[27,28]$. A phase I trial combining gefitinib, capecitabine and RT in rectal cancer patients resulted in significant toxicity [29]. An Italian Phase II study evaluating infusional 5FU with gefitinib and RT showed a pCR rate of $30 \%$ in 41 patients with clinical T3/4 or lymph node-positive rectal cancer [30]. However, a dose reduction was required in $61 \%$ of patients due to the severe toxicities reported, including grade III-IV gastrointestinal (21\%), hepatic (26\%), skin (15\%) and genitourinary (10\%) toxicities (Table 2). Further studies are needed to establish the feasibility and safety of gefitinb plus chemoradiotherapy. Ongoing phase I/II studies are evaluating the tolerability and efficacy of these small-molecule EGFR inhibitors with conventional neoadjuvant CRT regimens in patients with LARC.

\section{Vascular endothelial growth factor (VEGF) inhibition}

\subsection{Rationale}

Angiogenesis is necessary for tumor growth and malignant progression, being the VEGF a key pro-angiogenic factor. High VEGF expression was associated to progressive disease and poorer survival in several malignancies, including colon and rectal cancers [31-33]. The efficacy of inhibition of VEGF pathway is demonstrated by improvement of clinical outcome in patients affected by several advanced cancers [34]. In particular bevacizumab, a humanized monoclonal antibody inhibiting VEGF-A, in combination with standard chemotherapy regimens was beneficial both in term of response rate and survival as first- and second-line treatment of patients affected by mCRC. However, bevacizumab did not improve outcome as adjuvant therapy in stage III colorectal cancer when associated to oxaliplatinbased chemotherapy [35].

In patients affected by LARC who underwent radical surgery and adjuvant chemoradiation, tumor VEGF overexpression is associated with a statistically higher risk of local recurrence and metastasis [36]. 
Preclinical data suggested that proangiogenic factors, especially VEGF, are upregulated in tumors in response to radiotherapy and may increase the resistance to radiotherapy. Tumor production of angiogenic factors generates neo-blood vessels with architectural abnormalities that are associated with increased interstitial pressure and contribute to intratumoral hypoxia that, in turn, negatively affect the efficacy of both radiotherapy and chemotherapy. Experimental studies in human tumor xenografts showed that VEGF blockade reduces tumor interstitial pressure, by structural and functional remodeling of abnormal tumor blood vessels. This vascular "normalization" may transiently reduce tumor hypoxia and facilitate drug penetration into tumor mass, thereby enhancing response to chemotherapy and RT [37-40]. These attractive findings stimulated the clinical evaluation of anti-VEGF therapy in combination with conventional primary CRT in LARC (Table 1).

\subsection{Bevacizumab as radiosensitizer}

In the seminal study by Willett et al. [41-43] bevacizumab was delivered as i.v. infusion once before and 3 times during RT with infusional 5FU administered during radiation treatment. The primary objective of this phase I-II study was to determine the maximum tolerated dose of bevacizumab when delivered concurrently with 5FU and RT in patients with cT3/T4 rectal cancer before surgery as well as to clarify in vivo, through correlative studies, the mechanisms by which bevacizumab inhibits angiogenesis. The results on 32 patients showed tumor regression from a mean tumor size of $5 \mathrm{~cm}$ (range, $3-12 \mathrm{~cm}$ ) to an ulcer/scar with mean size of $2.4 \mathrm{~cm}$ (range, $0.7-6.0 \mathrm{~cm}$ ) in all patients and a $16 \%$ of pCR rate. Postoperative complications included anastomotic leak with presacral abscess requiring drainage $(n=1)$, vaginal tear $(n=1)$, pelvic hematoma $(n=1)$, and delayed healing of perineal incisions. The actuarial 5-year local control and OS were both $100 \%$ and 5-year DFS was $75 \%$, with 5 patients developing metastasis. The study also evaluated the biological effects of bevacizumab on rectal cancer before its concurrent administration with CRT. Before and 12 days after the first bevacizumab infusion patients underwent flexible sigmoidoscopy with tumor biopsy, tumor interstitial pressure measurement, perfusion computed tomography scan to measure blood flow, PET-FDG scan and analysis of blood and urine for a number of angiogenesis markers. Compared with baseline measurements evident antivascular effects were demonstrated, including lower tumor interstitial pressure, reduced tumor vascular density and increased pericyte coverage in tumor vessels.

The effect of bevacizumab on the activity of other radiosensitizer agents (infusional 5FU; capecitabine; capecitabine and oxaliplatin) has been evaluated in a number of phase II studies in LARC. In all these trials the primary end-point was pCR.

At the M.D. Anderson Cancer Center, Crane et al. [44] evaluated 25 patients affected by LARC (no T4 patients included) who received radiotherapy (50.4 Gy in 28 fractions over 5.5 weeks), capecitabine $\left(900 \mathrm{mg} / \mathrm{m}^{2}\right.$ twice daily, 5 days/week concomitantly with radiation) and bevacizumab $(5 \mathrm{mg} / \mathrm{kg}$ i.v. on days $1,15,29)$. Eight $(32 \%)$ patients obtained pCR, and for $6(24 \%)<10 \%$ viable tumor cells were detected in the surgical specimen. No patient experienced grade $3 / 4$ hand-foot syndrome, gastrointestinal toxicity or hematologic toxicity. However, 3 patients required surgical intervention due to wound complications (Table 2). With a median followup of 22.7 months (range, 4.5-32.4 months) all patients were alive; the 2-year actuarial rate was $6.2 \%$ (one patient showed a recurrence in the pelvis and 3 had distant recurrences). The sphincter-sparing rate was not evaluated.

In the largest phase II trial evaluating the activity of bevacizumab on patients affected by LARC, Velenik et al. [45] evaluated 61 patients with MRI-confirmed stage II/III rectal cancer who received bevacizumab $(5 \mathrm{mg} / \mathrm{kg}$ i.v. 2 weeks prior to CRT and on days 1, 15, 29), capecitabine $\left(825 \mathrm{mg} / \mathrm{m}^{2}\right.$ twice daily on days $\left.1-38\right)$ and concurrent radiotherapy ( $50.4 \mathrm{~Gy}$ in 28 fractions). The majority $(67 \%)$ of patients had $\mathrm{T} 3 n+$ tumors and another $8.2 \%$ had T4N2 tumors. Grade 3 adverse events included radiodermatitis $(9.8 \%)$, proteinuria $(6.5 \%)$ and leucocytopenia $(4.9 \%)$. TME radical resection was achieved in 57 patients $(95 \%)$, and 42 patients $(70 \%)$ underwent sphincter-preserving surgery. Dworak-TRG 4 (pCR) was found in $8(13.3 \%)$ patients and TRG 3 in further 9 (15\%) patients. Thirty-eight (62.3\%) patients developed perioperative complications, including delayed wound healing (30\%), infection/abscess (20\%) and anastomotic leakage $(11.7 \%)$. Six patients required surgical re-intervention for anastomotic leakage $(n=3)$, abdominal abscess $(n=2)$ and pneumothorax $(n=1)$ (Table 2).

Martinez Villacampa et al. evaluated in a randomized phase II trial the effect of adding bevacizumab $(5 \mathrm{mg} / \mathrm{kg}$ for 3 doses) (arm A) to preoperative capecitabine-based CRT $\left(825 \mathrm{mg} / \mathrm{m}^{2}\right.$ twice daily) (arm B) in 90 patients with stage II-III rectal cancer. In arm A, pCR was obtained by $7(16 \%)$ patients compared with $5(11 \%)$ patients $(p=0.54)$ in arm B. Overall grade $3 / 4$ toxicity rates were $18 \%$ and $13 \%$ (arm A versus $\mathrm{B} ; p=0.50$ ) and postoperative complications were 19 (43\%) in arm A and 17 (37\%) in arm B, respectively [46].

In a preliminary report of 23 patients with LARC from the Dutch Colorectal Cancer Group [47] bevacizumab $(5 \mathrm{mg} / \mathrm{kg}$ on days $-14,1,15,29)$ with concurrent capecitabine $\left(825 \mathrm{mg} / \mathrm{m}^{2}\right.$ twice daily) and radiation (50 Gy in 25 fractions) obtained pCR in 2 out 21 valuable patients. Grade 3 chemoradiation toxicities were experienced by 7 patients ( $\operatorname{ski} n=4$, diarrhea $=2$, tenesmus $=1$ ). One patient had grade 4 anal mucositis. Another patient with enteritis and diffuse bleeding at CRT-end, died before surgery. Two small bowel perforations occurred. Another patient had an asymptomatic rectal wall perforation at the site of the primary tumor. Surgical complications consisted of one perineal dehiscence, one rectovaginal fistula, and 1 patient had high-volume bleeding.

The Austrian Breast and Colorectal Cancer Study Group (ABCSG) reported the preliminary results of a phase II trial 
limited to cT3 rectal cancer patients [48]. The schedule of treatment included bevacizumab $(5 \mathrm{mg} / \mathrm{kg}$, days $1,15,29)$, capecitabine $\left(825 \mathrm{mg} / \mathrm{m}^{2}\right.$ twice daily on radiotherapy-days weeks 1-4) concurrently to pelvic radiotherapy (45 Gy in 5 weeks). Surgery followed 6-8 weeks later. Two (25\%) out of 8 patients obtained pCR and tumor downstaging was observed in $37.5 \%$ of patients. However, accrual had to be terminated according to protocol, since half of patients experienced grade 3 toxicity (intestinal bleeding, diarrhea, perianal/abdominal pain, anemia).

In our experience, 43 patients affected by LARC were enrolled in an Italian multicentre phase II trial to receive bevacizumab $(5 \mathrm{mg} / \mathrm{kg}$ on days $-14,1,15,29)$, capecitabine $\left(825 \mathrm{mg} / \mathrm{m}^{2}\right.$ twice a day for 5.5 weeks) concurrently with external-beam irradiation $(50.4 \mathrm{~Gy}$ in 28 fractions over 5.5 weeks). Post-operative histologic examination was centrally performed and showed no residual cancer cells both in the primary site of tumor and lymphodes (ypT0, N0) in 6 of the 43 patients (14\%; 95\% confidence limits: 3.6-24.3\%). In another 22 patients $(51.2 \%)$ a $\mathrm{v}<15 \%$ of cancer cells in residual areas of fibrosis/necrosis was found corresponding to Mandard TRG 2 or 3 classification. Tumor resection with negative circumferential margin of resection was achieved in $38(95 \%)$ out of 40 operated patients. Sphincter-sparing surgery was performed in $31(72.1 \%)$ patients. Primary tumor and lymph nodes downstaging was observed in 15 (34.9\%) and 16 (37.2\%) cases, respectively. G1-2 diarrhea, proctitis, rectal bleeding and hypertension were the most frequent side effects. Grade 3 toxicities were experienced by 5 patients, including diarrhea $(n=3,7.14 \%)$, neutropenia $(n=2)$, asthenia and hypokalemia $(n=1)$, respectively. Four $(9.52 \%)$ patients permanently discontinued CRT during the last week of treatment due to G3 adverse events. Of 7 patients who experienced serious adverse events one died of progressive disease and another died due to bowel perforation before receiving adjuvant treatment (1 month after surgery, 81 days after the last dose of bevacizumab). A patient presented failure of anastomosis ( 97 days after bevacizumab) and a patient experienced postoperative abscess ( 75 days after bevacizumab). Two patients were admitted to hospital due to G3 hypokaliemia and myocardial ischemia, respectively. In both cases, side-effects resolved with medical treatment. Only the latter patient was under adjuvant chemotherapy.

In this translational study aimed at identifying potential predictive indicators, we evaluated certain biomarkers related to microvessel density and expression of vascular endothelial growth factor receptor-2 (VEGFR-2), tumor associated macrophages (CD68 antibody) apoptosis (M30 antibody), cell kinetics (anti-Ki-67 labeling index), as well as antithymidine synthase and anti-thymidine phosphorylase being targets of fluoropyrimidines. No biomarker was significantly predictive of pCR nor of DFS. Pre-treatment vessel density by the panendothelial marker anti CD-34 antibody, posttreatment Ki-67 labeling index and VEGFR-2 cancer cells expression significantly correlated with residual tumor area [49].
In order to obtain better local control of disease from CRT, bevacizumab has been also evaluated in combinations with two cytotoxic chemosensitizers, such as 5FU/capecitabine and oxaliplatin in 3 studies.

In a pivotal phase I trial from Duke University the combination of capecitabine, oxaliplatin and bevacizumab was evaluated as primary treatment in patients with stage II to IV rectal cancer. Patients received escalating doses of capecitabine and oxaliplatin, with a fixed dose of bevacizumab. Two patients (18\%) achieved pCR and 3 patients focal microscopic disease only. One patient experienced a postoperative abscess, one a syncopal episode during adjuvant chemotherapy, and one a subclinical myocardial infarction during adjuvant chemotherapy [50].

Kennecke et al. [51] evaluated the safety and efficacy of pre-operative chemoradiation, using capecitabine $\left(825 \mathrm{mg} / \mathrm{m}^{2}\right.$ twice daily on days $1-14$ and $\left.22-35\right)$, oxaliplatin $\left(50 \mathrm{mg} / \mathrm{m}^{2}\right.$ on days $\left.1,8,22,29\right)$ and bevacizumab $(5 \mathrm{mg} / \mathrm{kg}$ on days $-14,1,15,29$ ) with standard doses of radiation in 42 patients with high-risk LARC with 18 (43\%) patients having cT4 and/or N2 tumors. TME was performed 7-9 weeks after CRT. Out of the 42 patients enrolled, 38 underwent radical surgery. Mean relative dose intensity was $>90 \%$ for all systemic agents, and $97 \%$ for radiation. Grade 3/4 diarrhea occurred in $10(24 \%)$ patients and pain in $4(10 \%)$ patients pre-operatively, while grade $3 / 4$ pain, fatigue and infection were each reported among 5 patients $(13 \%)$ post-operatively. Four (11\%) patients needed to be re-operated due to complications. The complete regression of primary tumor (ypT0) was seen in 9 patients (23.7\%), but two had N1 disease, therefore the pCR rate (ypT0N0) was $18.4 \%$. However, when the pathologic stage was centrally evaluated, the pCR was confirmed in six cases $(16 \%)$.

In another phase II trial in 70 patients with LARC, the addition of bevacizumab $(5 \mathrm{mg} / \mathrm{kg}$ on days $1,15,29)$ to capecitabine $\left(825 \mathrm{mg} / \mathrm{m}^{2}\right.$ bid on days $1-14$ and $\left.22-35\right)$, oxaliplatin $\left(50 \mathrm{mg} / \mathrm{m}^{2}\right.$ on days $\left.1,8,22,29\right)$ and standard RT (50.4 Gy in $1.8 \mathrm{~Gy}$ fractions) was well tolerated and did not lead to increased perioperative morbidity or mortality. Out of 69 patients who had surgery, 66 (96\%) patients had a R0 resection, $12(17.4 \%)$ obtained pCR. Pathological tumor downstaging as achieved in 32 (46.4\%) patients. CRT was well tolerated (toxicities are not available in details). The reported surgical complications included multivisceral resections (14\%), intraoperative (8\%) and postoperative complications $(43 \%)$, re-laparotomies (8\%), re-bleeding (3\%) and anastomotic leakages (5/40 anastomoses) requiring surgical interventions [52] (Table 2).

\subsection{Combining bevacizumab with induction chemotherapy (before CRT)}

The AVACROSS trial [53] recruited 47 patients affected by high-risk LARC defined by RMI criteria to assess the efficacy and toxicity of adding bevacizumab to induction chemotherapy followed by preoperative bevacizumab-based 
CRT. Treatment consisted of four every 21-day cycles of bevacizumab $(7.5 \mathrm{mg} / \mathrm{kg}$ ) in combination with CT (XELOX regimen), followed by concomitant radiotherapy (50.4 Gy) plus bevacizumab (5 mg/kg every 2 weeks) and capecitabine $\left(825 \mathrm{mg} / \mathrm{m}^{2}\right.$ twice daily on days $\left.1-15\right)$. Surgery was scheduled for 6-8 weeks after CRT. The primary end-point of the study was pCR. Among the 45 patients who underwent surgery, pCR was achieved in 16 patients $(36 \%$; $95 \%$ confidence interval: $22.2-51.2 \%$ ), and an additional 17 patients (38\%) had Dworak TRG 3. R0 resection was performed in 44 patients (98\%). Most grade 3/4 adverse events occurred during the induction phase and included diarrhea (11\%), asthenia $(4 \%)$, neutropenia $(6 \%)$, and thrombocytopenia $(4 \%)$. However, 11 patients (24\%) required surgical reintervention.

Dipetrillo et al. [54] reported the results of a small phase II study evaluating induction bevacizumab plus modified infusional 5FU, leucovorin, and oxaliplatin (mFOLFOX6) regimen followed by concurrent bevacizumab $(5 \mathrm{mg} / \mathrm{kg}$ on days $1,15,29)$, oxaliplatin $\left(50 \mathrm{mg} / \mathrm{m}^{2} /\right.$ week for 6 weeks $)$, continuous infusion $5 \mathrm{FU}\left(200 \mathrm{mg} / \mathrm{m}^{2} /\right.$ day $)$, and radiation in patients with LARC. Patients received 1 month of induction bevacizumab and mFOLFOX6 followed by $50.4 \mathrm{~Gy}$ of radiation and concurrent bevacizumab with CRT. Because of gastrointestinal toxicity oxaliplatin dose was reduced to $40 \mathrm{mg} / \mathrm{m}^{2} /$ week. Resection was performed $4-8$ weeks after the completion of chemoradiation. Unfortunately the trial was terminated early because of high grade toxicity after 26 eligible patients had been treated. Only 1 patient had significant toxicity (arrhythmia) during induction treatment and was removed from the study. During chemoradiation, grade 3/4 toxicity was experienced by 19 of 25 patients (76\%). The most common grade $3 / 4$ toxicities were diarrhea, neutropenia, and pain. Five (20\%) of 25 patients had pCR. Postoperative complications were experienced by $9(36 \%)$ out of 25, including infection ( $n=4)$, delayed healing $(n=3)$, leak/abscess $(n=2)$, sterile fluid collection $(n=2)$, ischemic colonic reservoir $(n=1)$, and fistula $(n=1)$ (Table 2).

\subsection{Bevacizumab as consolidation treatment (before surgery)}

As consolidation chemotherapy following CRT may improve pCR [55], bevacizumab in combination with FOLFOX [56] has been administered both concomitantly with, and following CRT, before surgery, in patients with LARC. However, these combinations were associated with an increased rate of post-surgical complications (21.4\%).

The feasibility of neoadjuvant chemotherapy (including an anti-angiogenic agent) without radiotherapy has been evaluated in patients with clinical stage II-III rectal cancer (no T4 tumors), who were candidates for sphinctersparing surgery [57]. The treatment regimen combined FOLFOX with bevacizumab without preoperative radiation and reported a pCR in 8/29 patients (27\%). Glynne-Jones et al. are evaluating in a randomised phase II study the efficacy and toxicity of neoadjuvant FOLFOX/bevacizumab versus
FOLFOXIRI/bevacizumab in resectable rectal cancer where preoperative MRI suggests adverse features such as extramural vascular invasion, but the circumferential resection margin (CRM) is not threatened. The primary end point is pCR. RT is not planned unless patients are shown to progress [58].

\section{Combining bevacizumab and EGFR inhibitors with CRT}

Despite the negative results reported in the Panitumumab Advanced Colorectal Cancer Evaluation (PACCE) trial [59], bevacizumab and cetuximab have been sequentially evaluated in combination with preoperative CRT in LARC. Preliminary results of a phase II trial have been recently presented [60]. Ten patients with K-RAS wild type tumor received an induction treatment with capecitabine $\left(2000 \mathrm{mg} / \mathrm{m}^{2}\right.$ day $\left.1-14\right)$, oxaliplatin $\left(130 \mathrm{mg} / \mathrm{m}^{2}\right)$ and bevacizumab $(7.5 \mathrm{mg} / \mathrm{kg})$ every 3 weeks for two cycles followed by capecitabine $\left(1300 \mathrm{mg} / \mathrm{m}^{2} /\right.$ day $)$ continuously during radiotherapy and cetuximab $400 \mathrm{mg} / \mathrm{m}^{2}$ every two weeks. The combination seems to be safe, with acceptable and manageable toxicities (Table 2).

Preliminary results of a phase I/II trial of bevacizumab $(5 \mathrm{mg} / \mathrm{kg}$ i.v. on days $1,15,29)$ and erlotinib $(50 / 100 / 150 \mathrm{mg}$ daily concomitantly with radiotherapy) in combination with infusional $5 \mathrm{FU}\left(225 \mathrm{mg} / \mathrm{m}^{2} /\right.$ day $)$ and standard pelvic radiotherapy for patients with cT3/4 rectal cancer have been reported [61]. No dose-limiting toxicities were registered. Erlotinib at a dose of $100 \mathrm{mg}$ was chosen as the MTD. Seven (47\%) out of 15 patients who completed the study treatment and underwent surgery obtained a pCR. At a median followup of 7 months, there were no local recurrences reported in patients who completed therapy. Grade 3/4 toxicities included lymphopenia $(59 \%)$, diarrhea $(24 \%)$, rash $(12 \%)$, cardiac ischemia (6\%), transaminitis (6\%), and mucositis (6\%). One patient had an anastomotic leak [62] (Table 2).

\section{Current challenges and future areas of research}

The advances in surgery, radiation and chemotherapy all integrated in a multidisciplinary approach have increased the rates of cure of patients with LARC. The use of TME has dramatically reduced local recurrence and more accurate radiation delivery techniques have lowered toxicity. Following the publication of the CAO/ARO/AIO-94 phase III trial, preoperative CRT with fluoropyrimidines followed by TME surgery is the standard therapy for LARC [63]. Local recurrence rate is now less than $7 \%$, being distant metastases the predominant type of treatment failure. Recent randomized trials on combined modality treatments, using either preoperative short-course radiotherapy alone or preoperative radiotherapy combined with $5 \mathrm{FU}$ failed to demonstrate further survival benefit $[64,65]$. Unsatisfactory results both in term of OS and $\mathrm{pCR}$ have been reported during tha last 5 years 
in phase III trials evaluating the addition of newer cytotoxic agents to standard radiation therapy.

Three TAs, cetuximab, panitumumab and bevacizumab, based on efficacy demonstrated in mCRC and on synergy with RT seen in preclinical models, have been evaluated in combination with CRT as neoadjuvant treatment of patients with LARC, being pCR the primary end-point in all the studies. These agents failed to improve pCR compared with standard regimens of fluoropyrimidine-based CRT.

However, in the absence up to now of direct comparative randomized phase III clinical trials is not possible to establish if the addition of TAs to standard CRT versus standard CRT alone improves or not clinical results in LARC. Concerning the side effects and the short time toxicity, bevacizumab enhances the risk of postoperative complications (bleeding, deep vein thrombosis, pelvic abscess, wound infection or dehiscence, perforation and enterocutaneous/perineal fistula). Similarly, the addition of EGFR inhibitors to standard CRT, besides the well know cutaneous toxicity, increases the incidence of gastrointestinal toxicities (abdominal pain, proctitis, diarrhea). The comparison of toxicity of the studies including TAs with the randomized clinical trials, such as CAO/ARO/AIO-94 and Dutch Colorectal Cancer Group trials, is not feasible because all the studies performed up to now on TAs in LARC are phase II studies, including very heterogeneous patient populations. An important question is if clinical evaluation of TAs in combination with CRT has been carried out in the optimal way. Several key issues should be reconsidered, including specific pharmacodynamic features of TAs and of their interactions with CRT, the parameters used to define efficacy of TAs when combined with CRT. Further aspects include the lack of reliable predictive factors of activity/efficacy and the analysis of possible biological and molecular peculiarities of rectal compared to colon cancer.

Bevacizumab and cetuximab exert their efficacy predominantly as cytostatic rather than cytotoxic agents, so it seems plausible that the benefits may not derive from an increased tumor shrinkage, but rather in slowering tumor progression. Therefore, it appears questionable that pCR is to be considered as the most suitable primary end-point $[64,66]$.

While there has been much debate about whether pCR is associated with a favorable long-term outcome, a recently published pooled analysis of data from 3105 patients enrolled in 14 studies suggested that patients with pCR after standard chemoradiation had better long-term outcome than those without pCR [66].

The residual tumor cells in mesorectal lymph nodes have been proposed as the most relevant independent prognostic factor for survival, even after total regression of the primary tumor after preoperative therapy. Therefore, tumor grading systems should include not just the regression of the primary tumor but also the residual disease in mesorectal lymph nodes. In addition, the accuracy of clinical staging techniques is quite different in defining $\mathrm{cT}, \mathrm{cN}$ and clinical "positivity" of the CRM, particularly in low-lying rectal cancer. Similarly, staging methods are non homogeneous in defining the CRM, which is the most accurate baseline factor in predicting local and distant relapse of disease.

\subsection{Clinicopathological issues}

\subsubsection{Predictive factors}

Antiangiogenic agents lack up to now of reliable predictive factors [67-69]. The study performed by Sleijfer et al. [70] in advanced soft tissue sarcoma in the context of EORTC-STBSG suggests that in patients treated with pazopanib, the determination of VEGFR-2 (low levels) and placental-derived growth factor (PIGF) (high levels) is associated to elevated toxicity and poor response rate. Other studies [41-43,71] suggest that angiogenic cytokines and circulating endothelial cells and their progenitors are potentially useful predictive factor in rectal cancer. However, the potential clinical use of these biomarkers needs further evaluation in prospective clinical trials.

Conversely, K-RAS mutational status is a negative predictive factor for cetuximab and panitumumab therapy. Surprisingly, in the randomized phase II EXPERT-C trial evaluating capecitabine and oxaliplatin with or without cetuximab as induction regimen followed by CRT with capecitabine and concomitant radiotherapy (without cetuximab) in patients with high-risk wild-type-KRAS LARC, cetuximab significantly increased the response rate and overall survival, but not pCR (the primary end-point of the trial) [24]. These data are in line with results from other three independent trials where patients with LARC received cetuximab combined with chemoradiation [72,73]. The clinical significance of determination of K-RAS, BRAF, PI3K/PTEN/AKT mutations, having a predictive role in anti-EGFR moAbtreatment in patients with $\mathrm{mCRC}$, remains to be specifically assessed in LARC patients.

An increasing number of studies performed with functional imaging techniques, including contrastenhanced dynamic MRI/computed tomography and 18F-fluorodeoxyglucose (18FDG) positron emission tomography in patients treated with standard CRT, shows the capability to obtain an early prediction of response by comparing basal versus intermediate evaluations of response to therapy [74-81].

Changes in imaging parameters have been suggested as indicators of tumor vessel function after bevacizumab monotherapy [82,83]. In a small cohort of 32 patients affected by LARC treated with standard radiation therapy, infusional 5FU and bevacizumab, functional imaging parameters revealed significant vascular and tumor responses after completion of the neoadjuvant treatment [43]. Blood flow and permeability-surface area product measured by dynamic computed tomography significantly decreased at day 12 and presurgery compared to pretreatment. These data suggest that VEGF blockade alone and with CRT decreases vascular permeability and induces pruning of the rectal cancer vasculature. In contrast, the 18FDG uptake (a measure of tumor metabolic rate) was not changed by bevacizumab alone, but 
significantly decreased by combination therapy [43]. However, these preliminary results need to be better evaluated in larger studies.

\subsubsection{New biomarkers and pharmacogenomic studies}

A plethora of potential histopathological, imaging and molecular predictive biomarkers have been evaluated by using single or multimarker assays and whole-genome analyses (Tables 3 and 4). Some of these biomarkers have great potential to stratify rectal cancer patients for personalized treatment regimens and to guide the implementation of targeted therapeutics as well. Gene and protein expression profiles appear to be the most promising approach since they better disclose the biological complexity of genetic and epigenetic aspects related to chemoradioresistance. However, none of these markers has been validated for selecting the optimal personalized treatment in individual patients. In addition, it should be considered that bioinformatics is an absolute requirement to analyse complex genomic data. Of particular interest appears the identification of a pharmacogenetic profile predictive of tumor response, following fluoropyrimidines-based CRT in rectal cancer patients. In a recent study [84], two polymorphisms were associated with response to CRT in a multivariate analysis: hOGG1-1245C $>\mathrm{G}$, which can affect radiosensitivity and MTHFR-677C $>\mathrm{T}$, which is involved in fluoropyrimidines activity. A differential tumor response has been associated to a specific genetic signature that allowed dividing patients into three groups with a different chance of tumor response. These data highlight that pharmacogenetic approaches could be useful to better identify patients who will benefit of neoadjuvant CRT. In addition, this approach may be used in defining the optimal personalized dose of radiosensitizer drugs, as shown for FOLFIRI in mCRC $[85,86]$.

\subsection{Pharmacodynamic considerations}

\subsubsection{Optimal sequence of targeted therapy and CRT}

A relevant issue is the optimal schedule of sequence of TAs with CRT. Both cetuximab and bevacizumab have been proposed as radiosensitizers, since they antagonize tumor radioresistance induced by EGFR and VEGF, respectively. Irradiation may activate the EGFR-pathway stimulating proliferative and pro-angiogenic effects, evasion of apoptosis and tumor progression. EGFR inhibitors antagonize these effects, leading to reduction in DNA-repair activities, to cell cycle blocking and to reduced proliferation and angiogenic activity. Inhibition of the MAPK/AKT pathways specifically prevents recovery of the cells after irradiation, leading to cell death and to better tumor response [72,73]. However, it has been suggested that the cytostatic effect of cetuximab might impair activity of cytotoxic agents that mainly act on proliferating cells $[72,73,87]$. EGFR inhibitors given before or concurrently with chemotherapy may antagonize the effect of cell-cycle dependent chemotherapy by inducing G1 arrest. The G1 cell cycle arrest caused by cetuximab reduces the radiosensitizing activity of fluoropyrimidines, oxaliplatin or irinotecan, mainly exerted in the S/G2/M phases [20]. These negative interactions are overcome by delivering cytotoxics before EGFR inhibitors [88]. These suggestions have been confirmed by in vivo studies [89] and ongoing clinical trials are evaluating these new sequences [73].

Well conducted in vitro and in vivo studies, provided direct evidence that bevacizumab may induce a "normalization" of tumor vessels by inhibiting VEGF-A [41]. The archistructural changes induce a number of biological events synergic with CRT, such as the reduction of interstitial blood pressure associated with increased permeability of vessels to drugs and decreased tumor hypoxia. Unfortunately, the "normalization window" is transient and, consequently, also the therapeutic benefits may be limited over time. In addition, antiangiogenic agents obtain a delay in tumor progression with a variable period of clinical benefit, rather than a tumor shrinkage [90-94]. Preclinical data suggests that the sequencing of chemotherapy, EGFR inhibition and radiation may be important. Other preclinical studies found that when antiangiogenc therapy is stopped, a rapid tumor revascularization is observed [93]. Similarly, when such agents are administered on discontinuous schedule tumors regrow [94]. Consistently, in clinical trials prolonged administration of bevacizumab has been associated to improved survival outcomes [95]. The suboptimal results obtained with bevacizumab-CRT clinical trials highlight that the optimal sequence of administering antiangiogenic agents in combination with cytotoxics and/or radiotherapy is yet to be optimized. There is also evidence that the sequence of oxaliplatin followed by cetuximab seems to be more effective than cetuximab before oxaliplatin [96].

Probably the optimal activity of TAs in LARC is related both to the direct on target activities and the off-target induced mechanisms of action with particular reference to antiangiogenic agents [97]. A deeper knowledge of the key molecular factors influencing tumor radioresistance would provide the opportunity to better modulate the activity of selective agents [98-102]. In several preclinical studies hypoxia modulating agents, inhibitors of the checkpoint kinases CHK1 and CHK2, of EGFR pathway kinases, of farnesyltransferase and of PI3K/ATM pathway and specific DNA repair inhibitors showed promising results [103].

\subsubsection{Exploring the inhibition of new targets}

Another strategy is to explore other key targets involved both in progression and in radioresistance of rectal cancer cells. It has been proposed that anti-VEGF therapy increases intratumoral hypoxia which, in turn, drives a genetic program resulting in elevation of c-Met expression and activity and EMT-mediated tumor cell invasion [104]. c-MET is also involved in signal transduction when EGFR and VEGFR are activated [105]. Multiple lines of evidence implicate hypoxia, HIF-1 $\alpha$, and c-Met activation in tumor aggressiveness. Blockade of both c-Met and VEGF signaling together, either by a combination of two selective agents or by a single multitargeted agent, might reduce tumor invasion and metastasis. 
Table 3

A selection of the studies that evaluated the predictive potential of single- or multi-biomarkers in patients affected by LARC.

\begin{tabular}{|c|c|c|c|c|c|c|}
\hline Authors & N. of pts & $\begin{array}{l}\text { Preoperative } \\
\text { treatment }\end{array}$ & Marker(s) & Method(s) & End-point(s) & Findings \\
\hline \multicolumn{7}{|c|}{ Single or multiple biomarkers } \\
\hline Giralt [112] & 87 & $4550.4 \mathrm{~Gy}$ & EGFR & $\mathrm{IHC}$ & $\mathrm{pCR}$ & $\begin{array}{l}\text { EGFR-positive expression before radiotherapy is an } \\
\text { indicator for poor response and low disease-free survival }\end{array}$ \\
\hline $\operatorname{Kim}[113]$ & 183 & $\begin{array}{l}50.4 \mathrm{~Gy} / 5 \mathrm{FU}+\mathrm{LV} \\
\text { or cap }+\mathrm{LV}\end{array}$ & EGFR & $\mathrm{IHC}$ & $\begin{array}{l}\text { Tumor downstaging } \\
\text { (defined as a } \\
\text { reduction of at least } \\
\text { one T-stage level) }\end{array}$ & $\begin{array}{l}\text { On logistic regression analysis, a low level of EGFR } \\
\text { expression was found as a significant predictive factor } \\
\text { for increased tumor downstaging }\end{array}$ \\
\hline Toyiama [114] & 40 & 5FU-based CRT & $\begin{array}{l}\text { EGFR, VEGF and } \\
\text { HIF-1 expression }\end{array}$ & RT-PCR & TRG & $\begin{array}{l}\text { The elevated expression level of each gene could predict } \\
\text { low response to CRT }\end{array}$ \\
\hline Carlomagno [115] & 43 & $\mathrm{RT} / \mathrm{cap}+$ oxa & $\begin{array}{l}\text { EGFR, VEGF, TS, } \\
\text { Ki67, poly(adenosine } \\
\text { diphosphate-ribose) } \\
\text { polymerase-1, } \\
\text { XRCC1 }\end{array}$ & $\mathrm{IHC}$ & $\begin{array}{l}\text { PR scored according } \\
\text { to } T R G(T R G 1=\text { pCR } \\
\text { versus } T R G \geq 2)\end{array}$ & $\begin{array}{l}\text { pCR was significantly associated with high TS, high } \\
\text { Ki67 and low EGFR expression }\end{array}$ \\
\hline Zlobec [116] & 104 & HDREB & $\begin{array}{l}\text { EGFR, VEGF, Bcl-2, } \\
\text { APAF-1, p53 }\end{array}$ & $\mathrm{IHC}$ & $\mathrm{pCR}$ & $\begin{array}{l}\text { In multivariable analysis, loss of VEGF and positive } \\
\text { EGFR both demonstrated independent predictive value } \\
\text { for pCR }\end{array}$ \\
\hline Debucquoy [117] & 99 & $\begin{array}{l}\mathrm{RT}(30 / 45 \mathrm{cGy}) \pm \\
5 \mathrm{FU} \pm \mathrm{LV}\end{array}$ & $\begin{array}{l}\text { EGFR, VEGF, CA IX, } \\
\text { Ki67, COX2 and } \\
\text { c-CK18 }\end{array}$ & TMA-IHC & $\begin{array}{l}\text { TRG according to } \\
\text { Dworak }\end{array}$ & $\begin{array}{l}\text { No predictive role for the biomarkers evaluated. Only } \\
\text { pre-treatment VEGF was associated to poor response }\end{array}$ \\
\hline Chang [118] & 130 & $50.4 \mathrm{~Gy} / 5 \mathrm{FU}+\mathrm{LV}$ & $\begin{array}{l}\text { Bax, Bcl2 p53, p21 } \\
\text { WAF1/CIP1, Ki67, } \\
\text { Ku-70, HDAC1, } \\
\text { MBGR4 }\end{array}$ & IHC & TRG & $\begin{array}{l}\text { Bax higher expression in the CR group as compared } \\
\text { with the PR group ( } 54 \% \text { versus } 29 \%, p=.017 \text { ) }\end{array}$ \\
\hline Kikuchi [119] & 60 & $45 \mathrm{~Gy} / \mathrm{S}-1+$ Iri & $\begin{array}{l}\text { Ki67 LI, Bax, TS, } \\
\text { DPD, MVD by CD34, } \\
\text { and Grp78 }\end{array}$ & $\mathrm{IHC}$ & $\begin{array}{l}\text { TRG according to } \\
\text { Dworak (responders: } \\
\text { TRG 3/4; } \\
\text { non-responders: } \\
\text { TRG1/2 }\end{array}$ & $\begin{array}{l}\text { On multiple logistic regression analysis, Ki67 LI, Bax, } \\
\text { and TS scores were found to be independent predictive } \\
\text { factors }\end{array}$ \\
\hline Negri [120] & 56 & $\begin{array}{l}40-45 \mathrm{~Gy} \pm \\
5 \mathrm{FU}+\text { oxa }\end{array}$ & $\begin{array}{l}\text { p53, p21,VEGF, TS, } \\
\text { MSH }\end{array}$ & IHC & $\begin{array}{l}\mathrm{pCR} \text { versus partial } \\
\text { responders versus non } \\
\text { responders }\end{array}$ & $\begin{array}{l}\text { No predictive value. High TS level was predictive of a } \\
\text { higher pathological response in the CRT subset } \\
(p=0.007)\end{array}$ \\
\hline Edden [121] & 152 & $\begin{array}{l}50.4 \mathrm{~Gy} / 5 \mathrm{FU} \text { or } \\
\text { cap }\end{array}$ & $\begin{array}{l}\text { APAF-1, Bax, BCL2, } \\
\text { p53, p21, p27, Cox2, }\end{array}$ & IHC & TRG & $\begin{array}{l}\text { On multivariate analysis, APAF- } 1 \text { was found to be } \\
\text { independently associated with good TRG }\end{array}$ \\
\hline
\end{tabular}

TRG (according to Dworak)

TMA-IHC

pCR

TMA-IHC

Tumor downstaging
Patients with MLH1-positive tumors had a higher pCR rate $(24.3 \%$ vs. $9.4 \% ; p=0.055)$

MIB tumor expression was an independent predictor of response to CRT ( $p=0.001)$ 
Table 3 (Continued)

\begin{tabular}{|c|c|c|c|c|c|c|}
\hline Authors & N. of pts & $\begin{array}{l}\text { Preoperative } \\
\text { treatment }\end{array}$ & Marker(s) & Method(s) & End-point(s) & Findings \\
\hline \multicolumn{7}{|c|}{ Single-nucleotide polymorphisms } \\
\hline $\begin{array}{l}\text { Ho-Pun-Cheung } \\
\text { [125] }\end{array}$ & 71 & 50 Gy/cap \pm Oxa & $\begin{array}{l}128 \text { SNPs over } 76 \\
\text { genes }\end{array}$ & $\begin{array}{l}\text { PCR and automated } \\
\text { sequencing }\end{array}$ & TRG (Dworak) & $\begin{array}{l}\text { The SNPs SOD2 rs } 4880 \text { and L13 rs } 1800925 \text { were } \\
\text { significantly associated with TRG }\end{array}$ \\
\hline $\begin{array}{l}\text { Garcia-Aguilar } \\
\quad[126]\end{array}$ & 132 & $50.4 \mathrm{~Gy} / 5 \mathrm{FU}$ & 23 genes & $\begin{array}{l}\text { PCR and automated } \\
\text { sequencing }\end{array}$ & $\begin{array}{l}\text { pCR versus non-pCR } \\
\text { according to ypTNM } \\
\text { staging system }\end{array}$ & $\begin{array}{l}\text { Patients with cyclin D1 G870A (AA) polymorphism, } \\
\text { and MTHFR C677T (TT) polymorphism or KRAS } \\
\text { mutation did not achieve a pCR }\end{array}$ \\
\hline Conradi [127] & 167 & $50.4 \mathrm{~Gy} / 5 \mathrm{FU} / \mathrm{oxa}$ & $\begin{array}{l}\text { TS gene } \\
\text { polymorphisms and } \\
\text { expression }\end{array}$ & $\begin{array}{l}\text { PCR and automated } \\
\text { sequencing }\end{array}$ & TRG & $\begin{array}{l}\text { No correlation was found between pretreatment TS } \\
\text { expression or TS genotype and TRG }\end{array}$ \\
\hline $\begin{array}{l}\text { Stoehlmacher } \\
\text { [128] }\end{array}$ & 40 & $50.4 \mathrm{~Gy} / 5 \mathrm{FU}$ & TYMS genotypes & $\begin{array}{l}\text { PCR and automated } \\
\text { sequencing }\end{array}$ & TRG & TS genotype and TRG were significantly correlated \\
\hline Paez [129] & 128 & $\begin{array}{l}45 \mathrm{~Gy} / 5 \mathrm{FU} \text { or } \\
\text { cap } \pm \text { oxa }\end{array}$ & $\begin{array}{l}\text { TS, EGFR, GSTP1, } \\
\text { and DNA repair genes } \\
\text { polymorphisms }\end{array}$ & $\begin{array}{l}\text { PCR and automated } \\
\text { sequencing }\end{array}$ & Pathologic response & $\begin{array}{l}\text { The } * 3 / * 3 \text { TS genotype was associated with a greater } \\
\text { rate of pCR and microfoci residual tumor }(59 \% \text { in } * 3 / * 3 \\
\text { vs. } 35 \% \text { in } * 2 / * 2 \text { and } * 2 / * 3 ; p=.013)\end{array}$ \\
\hline Spindler [130] & 60 & $65 \mathrm{~Gy} / \mathrm{UFT}$ & $\begin{array}{l}\text { TS, EGFR Sp1-216 } \\
\text { and EGF A61G gene } \\
\text { polymorphisms }\end{array}$ & $\begin{array}{l}\text { PCR and automated } \\
\text { sequencing }\end{array}$ & TRG & $\begin{array}{l}\text { The evaluated polymorphisms may be used in } \\
\text { combination as predictive markers for } \mathrm{pCR}\end{array}$ \\
\hline Hur [131] & 44 & 5FU-based CRT & $\begin{array}{l}\text { TS gene } \\
\text { polymorphisms and } \\
\text { expression }\end{array}$ & $\begin{array}{l}\mathrm{IHC} / \mathrm{PCR} \text { and } \\
\text { automated sequencing }\end{array}$ & $\begin{array}{l}\text { Tumor response } \\
\text { (TRG; pTNM) }\end{array}$ & $\begin{array}{l}\text { No significant difference in tumor response between } \\
\text { patients homozygous for } 3 R / 3 R \text { and patients } \\
\text { heterozygous for } 2 R / 3 R\end{array}$ \\
\hline Chiorean [132] & 28 & $\begin{array}{l}\text { Cap + Iri induc- } \\
\text { tion } \rightarrow 50.4 \text { Gy }+ \text { cap }\end{array}$ & $\begin{array}{l}\text { CES } 1 / 2, \text { TS, TP, DPD, } \\
\text { TOPO I, UGT } 1 \mathrm{~A} 1\end{array}$ & $\begin{array}{l}\text { PCR and automated } \\
\text { sequencing }\end{array}$ & $\mathrm{pCR}$ & $\begin{array}{l}\text { TP gene expression was higher in patients who obtained } \\
\text { pCR }\end{array}$ \\
\hline Balboa [133] & 65 & $\begin{array}{l}\text { 5FU or cap-based } \\
\text { CRT }\end{array}$ & $\begin{array}{l}\text { XRCC1, ERCC1, } \\
\text { ERCC2, MTHFR, } \\
\text { TYMS and EGFR } \\
\text { polymorphisms }\end{array}$ & $\begin{array}{l}\text { PCR and automated } \\
\text { sequencing }\end{array}$ & $\begin{array}{l}\text { TRG according to } \\
\text { Mandard score }\end{array}$ & $\begin{array}{l}\text { Only tumor XRCC1 appeared to be significantly } \\
\text { associated with T-downstaging }\end{array}$ \\
\hline Lamas [134] & 93 & $50.4 \mathrm{~Gy} / 5 \mathrm{FU}$ & $\begin{array}{l}\text { XRCC1, ERCC1, } \\
\text { MTHFR, EGFR, } \\
\text { DPD, and TYMS }\end{array}$ & $\begin{array}{l}\text { PCR and automated } \\
\text { sequencing }\end{array}$ & $\begin{array}{l}\text { TRG according to } \\
\text { Mandard score (TRG } \\
\text { 1/2: major response) }\end{array}$ & $\begin{array}{l}\text { Only germline polymorphisms of XRCC1 } \mathrm{G} / \mathrm{G} \text { and of } \\
\mathrm{TS}(2 \mathrm{R} / 3 \mathrm{G}, 3 \mathrm{C} / 3 \mathrm{G} \text {, and } 3 \mathrm{G} / 3 \mathrm{G}) \text { were independent } \\
\text { predictors of a TRG } 1 / 2\end{array}$ \\
\hline Villafranca [135] & 65 & $\begin{array}{l}45-54 \mathrm{~Gy} / 5 \mathrm{FU}+\mathrm{LV} \\
\text { or tegafur }+\mathrm{LV} \text { or } \\
5 \mathrm{FU}+\text { carbo or } \\
\text { oxa }\end{array}$ & $\begin{array}{l}\text { TYMS genotype from } \\
\text { tumor DNA }\end{array}$ & $\begin{array}{l}\text { PCR and automated } \\
\text { sequencing }\end{array}$ & T-stage downstaging & $\begin{array}{l}\text { TYMS } 2 / 2 \text { and TYMS } 2 / 3 \text { patients achieved higher } \\
\text { T-downstaging than those with TYMS } 3 / 3 \text { polymorphism }\end{array}$ \\
\hline Tan [136] & 135 & $45-50 \mathrm{~Gy} / 5 \mathrm{FU} \pm$ iri & $\begin{array}{l}\text { Germline TYMS } \\
\text { genotyping }\end{array}$ & $\begin{array}{l}\text { PCR and automated } \\
\text { sequencing }\end{array}$ & $\begin{array}{l}\text { Pathologic } \\
\text { T-downstaging (TDS) }\end{array}$ & $\begin{array}{l}\text { High rates of TDS and ypT0 were achieved among the } \\
\text { two risk groups (poor: TSER } * 3 / * 3 \text { or TSER } * 3 / * 4 \text {; } \\
\text { good: TSER } * 2 / * 2, * 2 / * 3 \text {, or } * 2 / * 4 \text { ) when treatment was } \\
\text { based on } T Y M S \text { genotype }\end{array}$ \\
\hline Terrazzino [137] & 125 & $\begin{array}{l}45-50.4 \mathrm{~Gy} / 5 \mathrm{FU} \pm \mathrm{LV} \\
\text { or } \\
5 \mathrm{FU}+\text { carbo/oxa }\end{array}$ & $\begin{array}{l}\text { TYMS genotype from } \\
\text { germline DNA } \\
\text { (blood) }\end{array}$ & $\begin{array}{l}\text { PCR and automated } \\
\text { sequencing }\end{array}$ & TRG & $\begin{array}{l}\text { No correlation was found between TYMS genotype and } \\
\text { TRG }\end{array}$ \\
\hline
\end{tabular}




\begin{tabular}{lllllll}
\hline Authors & N. of pts & $\begin{array}{l}\text { Preoperative } \\
\text { treatment }\end{array}$ & Marker(s) & Method(s) & End-point(s) & Findings \\
\hline
\end{tabular}

DNA mutations in EGFR-KRAS pathway

$50 \mathrm{~Gy} / 5 \mathrm{FU}$

KRAS

PCR-RFLP

ypUICC

Zauber [139]

53

$\mathrm{RT} / 5 \mathrm{FU} \pm \mathrm{LV}$

Kim [140]

82

50.4 Gy/iri +

cap \pm cetuximab

Gaedcke [141]

94

$50 \mathrm{~Gy} / 5 \mathrm{FU} \pm$ oxa

$A P C$ and DCC LOH,

KRAS mutations,

MSH

EGFR, KRAS, BRAF,

and PIK3CA mutation

status/EGFR and

PTEN expression

KRAS, BRAF

\section{PCR, DNA \\ sequencing}

Direct

sequencing/IHC

PCR, direct

sequencing

Grimminger [142]

130

45-50 Gy/cap \pm

oxa \pm cetuximab

EGFR, VEGF/R1-2,

ERCC1, TS

expression/KRAS and

BRAF mutational

status

Bengala [143] $\quad 146 \quad 50 \mathrm{~Gy} / 5 \mathrm{FU}$ or

$50 \mathrm{~Gy} / 5 \mathrm{FU}$
$\mathrm{cap} \pm$ oxa
EGFR gene copy

number/EGFR

expression/KRAS

APAF-1, apoptosis protease-activating factor 1; Cap, capecitabine; CA IX, carbonic anhydrase IX; Carbo, carboplatin; CES1/2, carboxylesterase-converting enzymes 1/2; c-CK18, cleaved cytokeratin 18; COX-2, cyclo-oxigenase 2; CR, complete response; CRT, chemoradiotherapy; CT, chemotherapy; DPD, dehydropyrimidine dehydrogenase; DS, downstaging; GSTP1, glutathione S-transferase P 1; EGFR, epidermal growth factor receptor; 5FU, 5-fluorouracil; HDAC-1, histone deacetylase 1; HDREB, high-dose-rate endorectal brachytherapy; IHC, immunohistochemistry; IL13, interleukin-13; Iri, irinotecan; KRAS, vKi-ras2 Kirsten rat sarcoma viral oncogene homolog; LI, labeling index; LV, leucovorin; MBGR-4, metabotropic glutamate receptor 4; MSH, microsatellite instability; MTHFR, methylenetetrahydrofolate reductase; MVD, microvessel density; Oxa, oxaliplatin; PCNA, proliferating cell nuclear antigen; PCR, polymerase chain reaction; PR, partial response; PTEN, phosphatase and tensin homolog; RT-PCR, real time protein chain reaction; SOD2, superoxide dismutase 2; SNPs, single-nucleotide polymorphisms; Tis, tumor in situ in the pathology specimen; TMA, tisse microarray, TOPO I, topoisomerase I; TP, thymidine phosphorylase; TYMS, thymidylate synthase gene; TS, thymidylate synthase; UGT, uridine-diphosphate glucuronosyl transferase 1A1; UFT, tegafur-uracil; VEGF, vascular endothelial growth factor; Wt, wild-type; XRCC1, X-ray cross-complementing group 1. 
Table 4

A selection of the studies that evaluated the predictive potential of chromosomal aberrations or gene/protein expression profiling in patients affected by LARC.

\begin{tabular}{|c|c|c|c|c|c|c|}
\hline Authors & N. of pts & Preoperative treatment & Marker(s) & Method & End-point(s) & Findings \\
\hline \multicolumn{7}{|c|}{ Chromosomal aberrations } \\
\hline Grade [144] & 42 & $50.4 \mathrm{~Gy} / 5 \mathrm{FU}$ & $\begin{array}{l}\text { Chromosomal copy } \\
\text { number alterations }\end{array}$ & $\mathrm{CGH}$ & T-downsizing & $\begin{array}{l}\text { Chromosomal gains of } 7 \mathrm{q} 32-\mathrm{q} 36 \text { and } \\
7 \mathrm{q} 11-\mathrm{q} 31 \text { as well as amplifications of } \\
20 \mathrm{q} 11-\mathrm{q} 13 \text { were associated with } \\
\text { responsiveness to preoperative CRT }\end{array}$ \\
\hline Chen [145] & 95 & $50.4 \mathrm{~Gy} / 5 \mathrm{FU}$ & $\begin{array}{l}\text { Chromosomal copy } \\
\text { number alterations }\end{array}$ & $\mathrm{CGH}$ & $\mathrm{pCR}$ & $\begin{array}{l}\text { Chromosomal loss of } 15 \mathrm{q} 11.1-\mathrm{q} 26.3 \text { was } \\
\text { associated with non-pCR, while loss of } \\
\text { 12p13.31 was associated with } \mathrm{pCR}\end{array}$ \\
\hline \multicolumn{7}{|l|}{ Gene profiling } \\
\hline Nishioka [146] & 17 & $40 \mathrm{~Gy} / \mathrm{S}-1$ & $\begin{array}{l}\text { Gene expression } \\
\text { profile }\end{array}$ & DNA microarray/IHC & $\begin{array}{l}\text { TRG (responders: } 0-1 \text { versus } \\
\text { non-responders: } 2-3 \text { ) }\end{array}$ & $\begin{array}{l}17 \text { genes were differentially expressed } \\
(p<0.05) \text { between responders and } \\
\text { non-responders }\end{array}$ \\
\hline Ghadimi [147] & 30 & $50.4 \mathrm{~Gy} / 5 \mathrm{FU}$ & $\begin{array}{l}\text { Gene expression } \\
\text { profile }\end{array}$ & DNA microarray & T-stage downstaging/TRG & $\begin{array}{l}\text { A set of } 54 \text { genes was differentially } \\
\text { expressed between responsive and resistant } \\
\text { tumors. Expression profiles could predict } \\
\text { tumor response (TRG) in } 83 \% \text { of patients }\end{array}$ \\
\hline Rimkus [148] & 43 & $45 \mathrm{~Gy} / 5 \mathrm{FU}$ & $\begin{array}{l}\text { Gene expression } \\
\text { profile }\end{array}$ & DNA microarray & TRG according to Mandard & $\begin{array}{l}42 \text { differentially expressed genes found, } \\
\text { expression profiles could accurately predict } \\
71 \% \text { of responders and } 86 \% \text { of } \\
\text { nonresponders }\end{array}$ \\
\hline Kim [149] & 46 & $50 \mathrm{~Gy} / 5 \mathrm{FU}$ & $\begin{array}{l}\text { Gene expression } \\
\text { profile }\end{array}$ & DNA microarray & TRG according to Dworak & $\begin{array}{l}261 \text { genes that were differentially expressed } \\
\text { between } 20 \text { partial responders and } 11 \\
\text { complete responders. Prediction accuracies } \\
\text { were } 84 \% \text { (training set) and } 87 \% \text { (test set), } \\
\text { respectively }\end{array}$ \\
\hline $\begin{array}{l}\text { Brettingham- } \\
\text { Moore } \\
{[150]}\end{array}$ & 51 & $50 \mathrm{~Gy} / 5 \mathrm{FU}$ & $\begin{array}{l}\text { Gene expression } \\
\text { profile }\end{array}$ & DNA microarray & $\begin{array}{l}\text { TRG according to Mandard, } \\
\text { metabolic response, and } \\
\text { UICC downstaging }\end{array}$ & $\begin{array}{l}\text { The sensitivity and specificity to predict } \\
\text { outcome CRT was } 82 \% \text { and } 89 \% \text {, } \\
\text { respectively }\end{array}$ \\
\hline Watanabe [151] & 52 & $50.4 \mathrm{~Gy}$ & $\begin{array}{l}\text { Gene expression } \\
\text { profile }\end{array}$ & DNA microarray & $\begin{array}{l}\text { TRG (responders: grade } 2 / 3 \text {; } \\
\text { non responders: grade } 0 / 1 \text { ) }\end{array}$ & $\begin{array}{l}\text { A set of } 33 \text { genes were differentially } \\
\text { expressed between responders and } \\
\text { nonresponders with a class prediction } \\
\text { accuracy of } 88.6 \%\end{array}$ \\
\hline \multicolumn{7}{|c|}{ Proteomic studies } \\
\hline Allal [152] & 17 & $50 \mathrm{~Gy} / 5 \mathrm{FU}$ or $\mathrm{Gem}$ & $\begin{array}{l}\text { Protein expression } \\
\text { profile }\end{array}$ & MALDI-TOF & $\begin{array}{l}\mathrm{pCR} \text { versus partial response, } \\
\text { versus no or minor response }\end{array}$ & $\begin{array}{l}\text { Of the } 56 \text { landmark proteins, those of } \\
\text { particular interest included tropomodulin, } \\
\text { heat shock protein, b-tubulin, annexin, } \\
\text { calsenilin, keratin type } 1 \text {, Notch } 2 \text { protein } \\
\text { homolog, and DNA repair protein RAD51L3 }\end{array}$ \\
\hline Smith [153] & 20 & $50 \mathrm{~Gy} / 5 \mathrm{FU}$ & $\begin{array}{l}\text { Protein expression } \\
\text { profile }\end{array}$ & SELDI-TOF-MS & TRG according to Mandard & $\begin{array}{l}\text { A cohort of } 14 \text { protein peaks that } \\
\text { differentiated good and poor responders to } \\
\text { CRT with } 87.5 \% \text { sensitivity and } 80 \% \\
\text { specificity }\end{array}$ \\
\hline
\end{tabular}

CGH, Comparative genomic hybridization; CRT, chemoradiotherapy; 5FU, 5-fluorouracil; Gem, gemcitabine; pCR, pathology complete response; S-1,; SELDI-TOF-MS, surface enhanced laser desorption/ionization time-of-flight mass spectrometry; TRG, tumor regression grade. 
It has been recently reported that ionizing radiation induces overexpression and activity of the MET oncogene through the ATM/NF- $\kappa$ B signaling pathway. MET protects cells from apoptosis thus supporting radioresistance and promotes cell invasion. It has been demonstrated in xenograft models that the treatment with MET inhibitors enhanced tumor cell radiosensitivity [106].

Finally, data from gene expression profile along with existing evidence for distinct regional embryological origin support the concept that distal colon normal tissue is biologically different from the proximal counterpart. Consistently, right-sided colon cancers are distinct clinicopathologic entities compared with distal and rectal carcinomas and carcinogenesis pathways appear to be distinct in colon and rectal cancer [107-110]. These differences should be taken into account in the development of future therapeutic approaches.

\section{Conclusion}

The addition of TAs and/or newer cytotoxic drugs to preoperative fluoropyrimidine-based chemoradiation for patients with LARC is a feasible strategy, but used in the current modalities it does not enhance pathologic downstaging and the excess in toxicity is not counterbalanced by significant improvements in local or distant control of disease. According to data from the MERCURY study [111], rectal cancer is one of the best oncological settings to test the relevance of dynamic techniques aspotential predictive indicatorsof neoadjuvant treatment efficacy in LARC. Therefore, future translational studies should be also aimed to incorporate imaging studies in patients treated with new targeted anticancer agents.

The neoadjuvant CRT offers a unique opportunity to investigate new combinations and innovative treatment strategies coupled with translational studies to develop predictive factors, by evaluating the molecular and biological mechanisms underlying tumor sensitivity and resistance to treatment. Well designed translational studies in the setting of primary CRT of LARC will enable oncologists to provide the optimal patient-tailored treatment, by sparing unnecessary surgery to complete responders.

\section{Conflict of interest statement}

The authors declare no conflict of interest.

\section{Reviewer}

Professor Peter Hohenberger, University of Heidelberg, Department of Surgery, Klinikum Mannheim, Theodor Kutzer Ufer, D-68135 Mannheim, Germany.

\section{Acknowledgement}

We thank the Associazione Italiana per la Ricerca sul Cancer (A.I.R.C.) for the support of our researches (Program 12214).

\section{References}

[1] http://Seer.cancer.gov/csr/1975_2009_pops09/[accessed 27.07.12].

[2] Gerard JP, Conroy T, Bonnetain F, et al. Preoperative radiotherapy with or without concurrent fluorouracil and leucovorin in T3-4 rectal cancers: results of FFCD 9203. Journal of Clinical Oncology 2006;24:4620-5.

[3] Bosset JF, Collette L, Calais G, et al. Chemotherapy with preoperative radiotherapy in rectal cancer. New England Journal of Medicine 2006;355:1114-23.

[4] Sauer R, Becker H, Hohenberger W, et al. Preoperative versus postoperative CRT for rectal cancer. New England Journal of Medicine 2004;351:1731-40.

[5] Bosset JF, Calais G, Mineur L, et al. Enhanced tumoricidal effect of chemotherapy with preoperative radiotherapy for rectal cancer: preliminary results-EORTC 22921. Journal of Clinical Oncology 2005;23:5620-7.

[6] Wollman R, Yahalom J, Maxy R, Pinto J, Fuks Z. Effect of epidermal growth factor on the growth and radiation sensitivity of human breast cancer cells in vitro. International Journal of Radiation Oncology, Biology, Physics 1994;30:91-8.

[7] Bonner J, Harari P, Giralt J, et al. Radiotherapy plsu cetuximab for squamous-cell carcinoma of the head and neck. New England Journal of Medicine 2006;354:567-78.

[8] Giralt J, de las Heras M, Cerezo L, et al. The expression of epidermal growth factor receptor results in a worse prognosis for patients with rectal cancer terated with preoperative radiotherapy: a multicenter, retrospective analysis. Radiotherapy and Oncology 2005;74:101-8.

[9] Kim J-S, Kim J-M, Li S, et al. Epidermal growth factor receptor as a predictor of tumor downstaging in locally advanmeed rectal cancer patients treated with preoperative chemoradiotherapy. International Journal of Radiation Oncology, Biology, Physics 2006;66:195-200.

[10] Koop R, Rothbauer E, Mueller E, Schildberg FW, Jauch KW, Pfeiffer A. Reduced survival of rectal cancer patients with increased tumor epidermal growth factor receptor levels. Diseases of the Colon and Rectum 2003;46:1391-9.

[11] van Cutsem E, Kohne CH, Hitre E, et al. Cetuximab and chemotherapy as initial treatment for metastatic colorectal cancer. New England Journal of Medicine 2009;360:1408-17.

[12] Cunningham D, Humblet Y, Siena S, et al. Cetuximab monotherapy and cetuximab plus irinotecan in irinotecan-refractory metastatic colorectal cancer. New England Journal of Medicine 2004;351:337-45.

[13] van Cutsem E, Peeters M, Siena S, et al. Open-label phase III trial of panitumumab plus best supportive care compared to best supportive care alone in patients with chemotherapy-refractory metastatic colorectal cancer. Journal of Clinical Oncology 2007;25:1658-64.

[14] Douillard JY, Siena S, Cassidy J, et al. Randomized, phase III trial of panitumumab with infusional fluorouracil, leucovorin, and oxaliplatin (FOLFOX4) versus FOLFOX4 alone as first-line treatment in patients with previously untreated metastatic colorectal cancer: the PRIME study. Journal of Clinical Oncology 2010;28:4697-705.

[15] Van Cutsem E, Köhne CH, Láng I, et al. Cetuximab plus irinotecan, fluorouracil, and leucovorin as first-line treatment for metastatic colorectal cancer: updated analysis of overall survival according to tumor KRAS and BRAF mutation status. Journal of Clinical Oncology 2011;29:2011-9.

[16] Marchetti A, Gasparini G. K-RAS and cetuximab in colorectal cancer. New England Journal of Medicine 2009;360:833-4. 
[17] Bertolini F, Chiara S, Bengala C, et al. Neoadjuvant treatment with single-agent cetuximab followed by f-FU, cetuximab, and pelvic radiotherapy: a phase II study in locally advanced rectal cancer. International Journal of Radiation Oncology, Biology, Physics 2009;73:466-72.

[18] Machiels JP, Sempoux C, Scalliet P, et al. Phase I/II study of preoperative cetuximab, capecitabine, and external beam radiotherapy in patients with rectal cancer. Annals of Oncology 2007;18:738-44.

[19] Velenik V, Ocvirk J, Oblak I, Anderluh F. A phase II study of cetuximab, capecitabine and radiotherapy in neoadjuvant treatment of patients with locally advanced resectable rectal cancer. European Journal of Surgical Oncology 2010;36:244-50.

[20] Rodel C, Arnold D, Hipp M, et al. Phase I-II trial of cetuximab, capecitabine, oxaliplatin, and radiotherapy as preoperative treatment in rectal cancer. International Journal of Radiation Oncology, Biology, Physics 2008;70:1081-6.

[21] McCollum AD, Kocs DM, Chada P, et al. A randomized phase II trial of preoperative chemoradiotherapy with or without cetuximab in locally advanced adenocarcinoma of the rectum. Journal of Clinical Oncology 2010;28:15s, abstr 3635 .

[22] Kim SY, Hong YS, Kim DY, et al. Preoperative chemoradiation with cetuximab, irinotecan, and capecitabine in patients with locally advanced resectable rectal cancer: a multicenter phase II study. International Journal of Radiation Oncology, Biology, Physics 2011;81:677-83.

[23] Horiseberger K, Treschl A, Mai S, et al. Cetuximab in combination with capecitabine, irinotecan, and radiotherapy for patients with locally advanced rectal cancer: results of a phase II MARGIT trial. International Journal of Radiation Oncology, Biology, Physics 2009;74:1487-93.

[24] Dewdney A, Cunningham D, Tabernero J, et al. Multicenter randomized phase ii clinical trial comparing neoadjuvant oxaliplatin, capecitabine, and preoperative radiotherapy with or without cetuximab followed by total mesorectal excision in patients with high risk recatl cancer (EXPERT-C). Journal of Clinical Oncology 2012;30:1620-7.

[25] Pinto C, Di Fabio F, Maiello E, et al. Phase II study of panitumumab, oxaliplatin, 5-fluoruracil, and concurrent radiotherapy as preoperative treatment in high-risk locally advanced rectal cancer patients (StarPan/STAR-02 Study). Annals of Oncology 2011;22:2424-30.

[26] Williams KJ, Telfer BA, Stratford IJ, Wedge SR. ZD1839 ("Iressa"), a specific oral epidermal growth factor receptor-tyrosine kinase inhibitor, potentiates radiotherapy in a human colorectal cancer xenograft model. British Journal of Cancer 2002;86:1157-61.

[27] Fisher G, Kuo T, Cho C, et al. Phase II study of gefitinib, fluorouracil, leucovorin, and oxaliplatin therapy in previously treated patients with metastatic colorectal cancer. Journal of Clinical Oncology 2005;23:5613-9.

[28] Gelibter AJ, Gamucci T, Pollera CF, et al. A phase II trial of gefitinib in combination with capecitabine and oxaliplatin as first-line chemotherapy in patients with advanced colorectal cancer. Current Medical Research and Opinion 2007;23:2117-23.

[29] Czito B, Willett C, Bendell J, et al. Increased toxicity with gefitinib, capecitabine and radiation therapy in pancreatic and rectal cancer. Phase I trial results. Journal of Clinical Oncology 2006;24: 656-62.

[30] Valentini V, De Paoli A, Gambacorta MA, et al. Infusional 5fluorouracil and ZD1839 (Gefitinib-Iressa) in combination with preoperative radiotherapy in patients with locally advanced rectal cancer: a phase I and II trial (1839IL/0092). International Journal of Radiation Oncology, Biology, Physics 2008;72:644-9.

[31] Hyodo I, Doi T, Endo H, et al. Clinical significance of plasma vascular endothelial growth factor in gastrointestinal cancer. European Journal of Cancer 1998;34:2041-5.

[32] Nanashima A, Ito M, Sekine I, et al. Significance of angiogenic factors in liver metastatic tumors originating from colorectal cancers. Digestive Diseases and Sciences 1998;43:2634-40.
[33] Chin K, Greenman J, Gardiner E, Kumar H, Topping K, Monson J. Pre-operative serum vascular endothelial growth factor can select patients for adjuvant treatment after curative resection in colorectal cancer. British Journal of Cancer 2000;83:1425-31.

[34] Gasparini G, Longo R, Toi M, Ferrara N. Angiogenic inhibitors: a new therapeutic strategy in oncology. Nature Clinical Practice Oncology 2005;2:562-77.

[35] Allegra CJ, Yothers G, O'Connell MJ, et al. Phase III trial assessing bevacizumab in stages II and III carcinoma of the colon: results of NSABP protocol C-08. Journal of Clinical Oncology 2011;29:11-6.

[36] Cascinu S, Garziano F, Catalano V, et al. An analysis of p53, BAX and vascular endothelial growth factor expression in node-positive rectal cancer. Relationships with tumour recurrence and event-free survival of patients treated with adjuvant chemoradiation. British Journal of Cancer 2002;86:744-9.

[37] Lee C, Heijin M, di Tomaso E, et al. Anti-vascular endothelial growth factor treatment augments tumor radiation response under normoxic or hypoxic conditions. Caner Research 2000;60:5565-70.

[38] Kozin SV, Boucher Y, Hicklin DJ, Bohlen P, Jain RK, Suit HD. Vascular endothelial growth factor receptor-2-blocking antibody potentiates radiation-induced long-term control of human tumor xenografts. Cancer Research 2001;61:39-44.

[39] Tong R, Boucher Y, Kozin S, Winkler F, Hicklin DJ, Jain RK. Vascular normalization by vascular endothelial growth factor receptor 2 blockage induces a pressure gradient across the vasculature and improves drug penetration in tumors. Cancer Research 2004;64:373-6.

[40] Winkler F, Kozin SV, Tong RT, et al. Kinetics of vascular normalization by VEGFR 2 blockade governs brain tumor response to radiation: role of oxygenation, angiopoietin-1, and matrix metalloproteinases. Cancer Cell 2004;6:553-63.

[41] Willett CG, Boucher Y, di Tomaso E, et al. Direct evidence that the VEGF-specific antibody bevacizumab has antivascular effects in human rectal cancer. Nature Medicine 2004;10:145-7.

[42] Willett CG, Boucher Y, Duda DG, et al. Surrogate markers for antiangiogenic therapy and dose-limiting toxicities for bevacizumab with radiation and chemotherapy: continued experience of a phase I trial in rectal cancer patients. Journal of Clinical Oncology 2005;23:8136-9.

[43] Willett C, Duda D, DiTomaso E, et al. Efficacy, safety, and biomarkers of neoadjuvant bevacizumab, radiation therapy, and 5-fluorouracil in rectal cancer: A multidisciplinary phase II study. Journal of Clinical Oncology 2009;27:3020-6.

[44] Crane CH, Eng C, Feig BW, et al. Phase II trial of neoadjuvant bevacizumab, capecitabine, and radiotherapy for locally advanced rectal cancer. International Journal of Radiation Oncology, Biology, Physics 2010;76:824-30.

[45] Velenik V, Ocvirk J, Music M, et al. Neoadjuvant capecitabine, radiotherapy, and bevacizumab (CRAB) in locally advanced rectal cancer: results of an open-label phase II study. Radiation Oncology 2011;6:105.

[46] Martinez Villacampa M, Capdevila J, Manzano JL, et al. A randomized phase II study of capecitabine-based chemoradiation with or without bevacizumab in resectable locally advanced rectal cancer. Journal of Clinical Oncology 2012;30(Suppl.), abstr 3571.

[47] Marijnen CA, Rutten H, de Wilt H, et al. Preoperative CRT regimen with capecitabine and bevacizumab in locally advanced rectal cancer: A feasibility study of the Dutch Colorectal Cancer Group (DCCG). Journal of Clinical Oncology 2008;26(20 Suppl.):abstr15040.

[48] Resch G, De Vries A, Öfner D, et al. Preoperative treatment with capecitabine, bevacizumab and radiotherapy for primary locally advanced rectal cancer - a two stage phase II clinical trial. Radiotherapy and Oncology 2012;102:10-3.

[49] Gasparini G, Torino F, Ueno T, et al. A phase II study of neoadjuvant bevacizumab plus capecitabine and concomitant radiotherapy in patients with locally advanced rectal cancer. Angiogenesis 2012;15:141-50.

[50] Czito BG, Bendell JC, Willett CG, et al. Bevacizumab, oxaliplatin, and capecitabine with radiation therapy in rectal cancer: phase I trial 
results. International Journal of Radiation Oncology, Biology, Physics 2007;68:472-8.

[51] Kennecke H, Berry S, Wong R, et al. Pre-operative bevacizumab, capecitabine, oxaliplatin and radiation among patients with locally advanced or low rectal cancer: a phase II trial. European Journal of Cancer 2012;48:37-45.

[52] Hoehler T, Dellas K, Riesenbeck D, et al. Preoperative chemoradiation (CRT) with concurrent capecitabine (Cap), oxaliplatin (Ox), and bevacizumab (Bev) in patients with locally advanced rectal cancer (RC): effects on pathological complete response (pCR) and surgical complications. Journal of Clinical Oncology 2011;29(Suppl.), abstr 3630.

[53] Nogué M, Salud A, Vicente P, et al. AVACROSS Study Group. Addition of bevacizumab to XELOX induction therapy plus concomitant capecitabine-based CRT in magnetic resonance imaging-defined poor-prognosis locally advanced rectal cancer: the AVACROSS study. Oncologist 2011;16:614-20.

[54] Dipetrillo T, Pricolo V, Lagares-Garcia J, et al. Neoadjuvant bevacizumab, oxaliplatin, 5-fluorouracil, and radiation for rectal cancer. International Journal of Radiation Oncology, Biology, Physics 2012;82:124-9.

[55] Habr-Gama A, Perez RO, Sabbaga J, Nadalin W, São Julião GP, GamaRodrigues J. Increasing the rates of complete response to neoadjuvant chemoradiation for distal rectal cancer: results of a prospective study using additional chemotherapy during the resting period. Diseases of the Colon and Rectum 2009;52:1927-34.

[56] Liang JT, Lai HS, Cheng KW. Technical feasibility of laparoscopic total mesorectal excision for patients with low rectal cancer after concurrent radiation and chemotherapy with bevacizumab plus FOLFOX. Surgical Endoscopy 2011;25:305-8.

[57] Schrag D, Weiser MR, Goodman KA, et al. Neoadjuvant FOLFOXbev, without radiation, for locally advanced rectal cancer. Journal of Clinical Oncology 2010;28(15 Suppl.):abstr3511.

[58] Glynne-Jones R, Anyamene N, Moran B, Harrison M. Neoadjuvant chemotherapy in MRI-staged high-risk rectal cancer in addition to or as an alternative to preoperative chemoradiation? Annals of Oncology 2012, http://dx.doi.org/10.1093/annonc/mds010.

[59] Hecht JR, Mitchell E, Chidiac T, et al. A randomized phase IIIB trial of chemotherapy, bevacizumab, and panitumumab compared with chemotherapy and bevacizumab alone for metastatic colorectal cancer. Journal of Clinical Oncology 2009;27:672-80.

[60] Elvira G, Torrecillas L, Cervantes G, Erzao Valle Solis AA. Phase II study of bevacizumab and cetuximab as neoadjuvant treatment in locally advanced rectal cancer: a preliminary security report. Journal of Clinical Oncology 2011;29(Suppl. 4), abstr 627.

[61] Blaszkowsky LS, Hong TS, Zhu AX, et al. A phase I/II study of bevacizumab, erlotinib, and 5-fluorouracil with concurrent external beam radiation therapy in locally advanced rectal cancer. Journal of Clinical Oncology 2009;27(15S), abst 4106.

[62] Wadlow RC, Ryan DP. The role of targeted agents in preoperative chemoradiation for rectal cancer. Cancer 2010;116:3537-48.

[63] Cunningham D, Atkin W, Lenz HJ, et al. Colorectal cancer. Lancet 2010;375:1030-47, http://dx.doi.org/10.1016/S0140-6736(10)60353-4.

[64] Sauer R, Liersch T, Merkel S, et al. Preoperative versus postoperative chemoradiotherapy for locally advanced rectal cancer: results of the German CAO/ARO/AIO-94 randomized phase III trial after a median follow-up of 11 years. Journal of Clinical Oncology 2012;30:1926-33.

[65] Van Gijn W, Marijnen CA, Nagtegaal ID, et al. Preoperative radiotherapy combined with total mesorectal excision for resectable rectal cancer: 12-year follow-up of the multicentre, randomised controlled TME trial. Lancet Oncology 2011;12:575-82.

[66] Maas M, Nelemans PJ, Valentini V, et al. Long-term outcome in patients with a pathological complete response after chemoradiation for rectal cancer: a pooled analysis of individual patient data. Lancet Oncology 2010;11:835-44.
[67] Longo R, Gasparini G. Challenges for patient selection with VEGF inhibitors. Cancer Chemotherapy and Pharmacology 2007;60:151-70.

[68] Jubb AM, Harris AL. Biomarkers to predict the clinical efficacy of bevacizumab in cancer. Lancet Oncology 2010;11:1172-83.

[69] Abajo A, Boni V, Lopez I, et al. Identification of predictive circulating biomarkers of bevacizumab-containing regimen efficacy in pre-treated metastatic colorectal cancer patients. British Journal of Cancer 2012;107:287-90.

[70] Sleijfer S, Gorlia T, Lamers C, et al. Cytokine and angiogenic factors associated with efficacy and toxicity of pazopanib in advanced softtissue sarcoma: an EORTC-STBSG study. British Journal of Cancer 2012;107:639-45.

[71] Duda DG, Cohen KS, di Tomaso E, et al. Differential CD146 expression on circulating versus tissue endothelial cells in rectal cancer patients: implications for circulating endothelial and progenitor cells as biomarkers for antiangiogenic therapy. Journal of Clinical Oncology 2006;24:1449-53.

[72] Debucquoy A, Haustermans K, Daemen A, et al. Molecular response to cetuximab and efficacy of preoperative cetuximabbased chemoradiation in rectal cancer. Journal of Clinical Oncology 2009;27:2751-7.

[73] Debucquoy A, Machiels JP, McBride WH, Haustermans K. Integration of epidermal growth factor receptor inhibitors with preoperative chemoradiation. Clinical Cancer Research 2010;16: 2709-14.

[74] Patel UB, Brown G, Rutten H, et al. Comparison of magnetic resonance imaging and histopathological response to chemoradiotherapy in locally advanced rectal cancer. Annals of Surgical Oncology 2012;19:2842-52

[75] Park IJ, You YN, Agarwal A, et al. Neoadjuvant treatment response as an early response indicator for patients with rectal cancer. Journal of Clinical Oncology 2012;30:1770-6.

[76] Nougaret S, Rouanet P, Molinari N, et al. MR volumetric measurement of low rectal cancer helps predict tumor response and outcome after combined chemotherapy and radiation therapy. Radiology 2012;263:409-18.

[77] Barbaro B, Vitale R, Valentini V, et al. Diffusion-weighted magnetic resonance imaging in monitoring rectal cancer response to neoadjuvant chemoradiotherapy. International Journal of Radiation Oncology, Biology, Physics 2012;83:594-9.

[78] Janssen MH, Ollers MC, van Stiphout RG, et al. Evaluation of early metabolic responses in rectal cancer during combined radiochemotherapy or radiotherapy alone: sequential FDG-PET-CT findings. Radiotherapy and Oncology 2010;94:151-5.

[79] Goldberg N, Kundel Y, Purim O, et al. Early prediction of histopathological response of rectal tumors after one week of preoperative radiochemotherapy using 18 F-FDG PET-CT imaging. A prospective clinical study. Radiation Oncology 2012;1(7):124.

[80] Hatt M, van Stiphout R, le Pogam A, Lammering G, Visvikis D, Lambin P. Early prediction of pathological response in locally advanced rectal cancer based on sequential (18)F-FDG PET. Acta Oncologica 2012, http://dx.doi.org/10.3109/0284186X.2012.702923.

[81] Perez RO, Habr-Gama A, Gama-Rodrigues J, et al. Accuracy of PET/CT and clinical assessment in the detection of complete rectal tumor regression following neoadjuvant chemoradiation. Long-term results of a prospective trial (NCT00254683). Cancer 2011;118:3501-11.

[82] Jain RK. Normalization of tumor vasculature: an emerging concept in antiangiogenic therapy. Science 2005;307:58-62.

[83] Jain RK, Duda DG, Clark JW, Loeffler JS. Lessons from phase III clinical trials on anti-VEGF therapy for cancer. Nature Clinical Practice Oncology 2006;3:24-40.

[84] Cecchin E, Agostini M, Pucciarelli S, et al. Tumor response is predicted by patient genetic profile in rectal cancer patients treated with neo-adjuvant chemo-radiotherapy. Pharmacogenomics Journal 2011;11:214-26. 
[85] Toffoli G, Cecchin E, Gasparini G, et al. Genotype-driven phase I study of irinotecan administered in combination with fluorouracil/leucovorin in patients with metastatic colorectal cancer. Journal of Clinical Oncology 2010;28:866-71.

[86] Toffoli G, D'Andrea MR, Gasparini G. Irinotecan in the adjuvant treatment of colon cancer: is the story finished or does personalized therapy open new opportunities? Journal of Clinical Oncology 2010;28:e199.

[87] Rodel C, Grabenbauer GG, Papadopoulos T, et al. Apoptosis as a cellular predictor for histopathologic response to neoadjuvant radiochemotherapy in patients with rectal cancer. International Journal of Radiation Oncology, Biology, Physics 2002;52:294-303.

[88] Nyati MK, Morgan MA, Feng FY, Lawrence TS. Integration of EGFR inhibitors with radiochemotherapy. Nature Reviews Cancer 2006;6:876-85.

[89] Milas L, Fang FM, Mason KA, et al. Importance of maintenance therapy in C225-induced enhancement of tumor control by fractionated radiation. International Journal of Radiation Oncology, Biology, Physics 2007;67:568-72.

[90] Bergers G, Hanahan D. Modes of resistance to anti-angiogenic therapy. Nature Reviews Cancer 2008;8:592-603.

[91] Kerbel RS, Yu J, Tran J, et al. Possible mechanisms of acquired resistance to anti-angiogenic drugs: implications for the use of combination therapy approaches. Cancer and Metastasis Reviews 2001;20:79-86.

[92] Miller KD, Sweeney CJ, Sledge Jr GW. Can tumor angiogenesis be inhibited without resistance? EXS 2005;94:95-112.

[93] Mancuso MR, Davis R, Norberg SM, et al. Rapid vascular regrowth in tumors after reversal of VEGF inhibition. Journal of Clinical Investigation 2006;116:2610-21.

[94] Burstein HJ, Elias AD, Rugo HS, et al. Phase II study of sunitinib malate, an oral multitargeted tyrosine kinase inhibitor, in patients with metastatic breast cancer previously treated with an anthracycline and a taxane. Journal of Clinical Oncology 2008;26:1810-6.

[95] Grothey A, Sugrue MM, Purdie DM, et al. Bevacizumab beyond first progression is associated with prolonged overall survival in metastatic colorectal cancer: results from a large observational cohort study (BRiTE). Journal of Clinical Oncology 2008;26:5326-34.

[96] Morelli MP, Cascone T, Troiani T, et al. Sequence-dependent antiproliferative effects of cytotoxic drugs and epidermal growth factor receptor inhibitors. Annals of Oncology 2005;16(Suppl. 4): iv61-8.

[97] Cao Y, Arbiser J, D’ Amato RJ, et al. Forty-year journey of angiogenesis translational research. Science Translation Medicine 2011;3(114), $114 \mathrm{rv} 3$.

[98] Gasparini G, Gattuso D, Morabito A, et al. Combined therapy with weekly irinotecan, infusional 5-fluorouracil and the selective COX-2 inhibitor rofecoxib is a safe and effective second-line treatment in metastatic colonrectal cancer. The Oncologist 2005;10:710-7.

[99] Tortora G, Ciardiello F, Gasparini G. Combined targeting of ErbB-and VEGF-dependent pathways: rationale, preclinical studies and clinical applications. Nature Clinical Practice Oncology 2008;5:521-30.

[100] Gasparini G, Longo R, Torino F, Toffoli G, Barone C. Tailored therapy of colorectal cancer: results, challenges and future directions. Cancer Journal 2005; 11:175-88.

[101] Gasparini G, Longo R, Torino F, Gattuso D, Morabito A, Toffoli G. Is tailored therapy feasible in oncology? Critical Reviews in Oncology/Hematology 2006;57:79-101.

[102] Rau B, Sturm I, Lage H, et al. Dynamic expression profile of p21WAF1/CIP1 and Ki-67 predicts survival in rectal carcinoma treated with preoperative radiochemotherapy. Journal of Clinical Oncology 2003;21:3391-401.

[103] Begg AC, Stewart FA, Vens C. Strategies to improve radiotherapy with targeted drugs. Nature Reviews Cancer 2011;11:239-53.

[104] Sennino B, Ishiguro-Oonuma T, Wei Y, et al. Suppression of tumor invasion and metastasis by concurrent inhibition of c-Met and VEGF signaling in pancreatic neuroendocrine tumors. Cancer Discovery 2012;2:270-87.
[105] Ding S, Merkulova-Rainon T, Han ZC, Tobelem G. HGF receptor upregulation contributes to the angiogenic phenotype of human endothelial cells and promotes angiogenesis in vitro. Blood 2003;101:4816-22.

[106] De Bacco F, Luraghi P, Medico E, et al. Induction of MET by ionizing radiation and its role in radioresistance and invasive growth of cancer. Journal of the National Cancer Institute 2011;103:645-61.

[107] Birkenkamp-Demtroder K, Olesen SH, Sørensen FB, et al. Differential gene expression in colon cancer of the caecum versus the sigmoid and rectosigmoid. Gut 2005;54:374-84.

[108] Hong TS, Clark JW, Haigis KM. Cancers of the colon and rectum: identical or fraternal twins? Cancer Discovery 2012;2:117-21.

[109] Minoo P, Zlobec I, Peterson M, Terracciano L, Lugli A. Characterization of rectal, proximal and distal colon cancers based on clinicopathological, molecular and protein profiles. International Journal of Oncology 2010;37:707-18, http://dx.doi.org/10.3892/ijo_00000720.

[110] Li JN, Zhao L, Wu J, et al. Differences in gene expression profiles and carcinogenesis pathways between colon and rectal cancer. Journal of Digestive Disease 2012;13:24-32, http://dx.doi.org/10.1111/j.1751-2980.2011.00551.x.

[111] Patel UB, Taylor F, Blomqvist L, et al. Magnetic resonance imagingdetected tumor response for locally advanced rectal cancer predicts survival outcomes: MERCURY experience. Journal of Clinical Oncology 2011;29:3753-60.

[112] Giralt J, de las Heras M, Cerezo L, et al. The expression of epidermal growth factor receptor results in a worse prognosis for patients with rectal cancer treated with preoperative radiotherapy: a multicenter, retrospective analysis. Radiotherapy and Oncology 2005;74:101-8.

[113] Kim JS, Kim JM, Li S, et al. Epidermal growth factor receptor as a predictor of tumor downstaging in locally advanced rectal cancer patients treated with preoperative chemoradiotherapy. International Journal of Radiation Oncology, Biology, Physics 2006;66:195-200.

[114] Toiyama Y, Inoue Y, Saigusa S, et al. Gene expression profiles of epidermal growth factor receptor, vascular endothelial growth factor and hypoxia-inducible factor- 1 with special reference to local responsiveness to neoadjuvant chemoradiotherapy and disease recurrence after rectal cancer surgery. Clinical Oncology (Royal College of Radiologists) 2010;22:272-80.

[115] Carlomagno C, Pepe S, D'Armiento FP, et al. Predictive factors of complete response to neoadjuvant chemoradiotherapy in patients with rectal cancer. Oncology 2010;78:369-75.

[116] Zlobec I, Vuong T, Compton CC, et al. Combined analysis of VEGF and EGFR predicts complete tumour response in rectal cancer treated with preoperative radiotherapy. British Journal of Cancer 2008;98:450-6.

[117] Debucquoy A, Goethals L, Libbrecht L, et al. Molecular and clinicopathological markers in rectal cancer: a tissue micro-array study. International Journal of Colorectal Disease 2009;24:129-38.

[118] Chang HJ, Jung KH, Kim DY, et al. Bax, a predictive marker for therapeutic response to preoperative chemoradiotherapy in patients with rectal carcinoma. Human Pathology 2005;36:364-71.

[119] Kikuchi M, Mikami T, Sato T, et al. High Ki67, Bax, and thymidylate synthase expression well correlates with response to chemoradiation therapy in locally advanced rectal cancers: proposal of a logistic model for prediction. British Journal of Cancer 2009;101:116-23.

[120] Negri FV, Campanini N, Camisa R, et al. Biological predictive factors in rectal cancer treated with preoperative radiotherapy or radiochemotherapy. British Journal of Cancer 2008;98:143-7.

[121] Edden Y, Wexner SD, Berho M. The use of molecular markers as a method to predict the response to neoadjuvant therapy for advanced stage rectal adenocarcinoma. Colorectal Disease 2012;14:555-61, http://dx.doi.org/10.1111/j.1463-1318.2011.02697.x.

[122] Bertolini F, Bengala C, Losi L, et al. Prognostic and predictive value of baseline and posttreatment molecular marker expression in locally advanced rectal cancer treated with neoadjuvant chemoradiotherapy. International Journal of Radiation Oncology, Biology, Physics 2007;68:1455-61. 
[123] Huerta S, Hrom J, Gao X, et al. Tissue microarray constructs to predict a response to chemoradiation in rectal cancer. Digestive and Liver Disease 2010;42:679-84.

[124] Kim K, Chie EK, Wu HG, et al. High survivin expression as a predictor of poor response to preoperative chemoradiotherapy in locally advanced rectal cancer. International Journal of Colorectal Disease 2011;26:1019-23.

[125] Ho-Pun-Cheung A, Assenat E, Bascoul-Mollevi C, et al. A largescale candidate gene approach identifies SNPs in SOD2 and IL13 as predictive markers of response to preoperative chemoradiation in rectal cancer. Pharmacogenomics Journal 2011;11:437-43, http://dx.doi.org/10.1038/tpj.2010.62.

[126] Garcia-Aguilar J, Chen Z, Smith DD, et al. Identification of a biomarker profile associated with resistance to neoadjuvant chemoradiation therapy in rectal cancer. Annals of Surgery 2011;254:486-92.

[127] Conradi LC, Bleckmann A, Schirmer M, et al. Thymidylate synthase as a prognostic biomarker for locally advanced rectal cancer after multimodal treatment. Annals of Surgical Oncology 2011;18:2442-52, http://dx.doi.org/10.1245/s10434-011-1608-4.

[128] Stoehlmacher J, Goekkurt E, Mogck U, et al. Thymidylate synthase genotypes and tumour regression in stage II/III rectal cancer patients after neoadjuvant fluorouracil-based chemoradiation. Cancer Letters 2008;272:221-5

[129] Páez D, Salazar J, Paré L, et al. Pharmacogenetic study in rectal cancer patients treated with preoperative chemoradiotherapy: polymorphisms in thymidylate synthase, epidermal growth factor receptor, GSTP1, and DNA repair genes. International Journal of Radiation Oncology, Biology, Physics 2011;81:1319-27.

[130] Spindler KL, Nielsen JN, Lindebjerg J, Lindebjerg J. Germline polymorphisms may act as predictors of response to preoperative chemoradiation in locally advanced T3 rectal tumors. Diseases of the Colon and Rectum 2007;50:1363-9.

[131] Hur H, Kang J, Kim NK, et al. Thymidylate synthase gene polymorphism affects the response to preoperative 5-fluorouracil chemoradiation therapy in patients with rectal cancer. International Journal of Radiation Oncology, Biology, Physics 2011;81:669-76.

[132] Chiorean EG, Sanghani S, Schiel MA, et al. Phase II and gene expression analysis trial of neoadjuvant capecitabine plus irinotecan followed by capecitabine-based chemoradiotherapy for locally advanced rectal cancer: Hoosier Oncology Group GI03-53. Cancer Chemotherapy and Pharmacology 2012:18, http://dx.doi.org/10.1007/s00280-012-1883-1.

[133] Balboa E, Duran G, Lamas MJ, et al. Pharmacogenetic analysis in neoadjuvant chemoradiation for rectal cancer: high incidence of somatic mutations and their relation with response. Pharmacogenomics 2010;11:747-61.

[134] Lamas MJ, Duran G, Gomez A, et al. X-ray cross-complementing group 1 and thymidylate synthase polymorphisms might predict response to chemoradiotherapy in rectal cancer patients. International Journal of Radiation Oncology, Biology, Physics 2012;82:138-44.

[135] Villafranca E, Okruzhnov Y, Dominguez MA, et al. Polymorphisms of the repeated sequences in the enhancer region of the thymidylate synthase gene promoter may predict downstaging after preoperative chemoradiation in rectal cancer. Journal of Clinical Oncology 2001;19:1779-86.

[136] Tan BR, Thomas F, Myerson RJ, et al. Thymidylate synthase genotype-directed neoadjuvant chemoradiation for patients with rectal adenocarcinoma. Journal of Clinical Oncology 2011;29:875-83.

[137] Terrazzino S, Agostini M, Pucciarelli S, et al. A haplotype of the methylenetetrahydrofolate reductase gene predicts poor tumor response in rectal cancer patients receiving preoperative chemoradiation. Pharmacogenet Genomics 2006;16:817-24.

[138] Luna-Perez P, Segura J, Alvarado I, Labastida S, Santiago-Payan $\mathrm{H}$, Quintero A. Specific c-K-ras gene mutations as a tumorresponse marker in locally advanced rectal cancer treated with preoperative chemoradiotherapy. Annals of Surgical Oncology 2000;7: 727-31.
[139] Zauber NP, Marotta SP, Berman E, et al. Molecular genetic changes associated with colorectal carcinogenesis are not prognostic for tumor regression following preoperative chemoradiation of rectal carcinoma. International Journal of Radiation Oncology, Biology, Physics 2009;74:472-6.

[140] Kim SY, Shim EK, Yeo HY, et al. KRAS mutation status and clinical outcome of preoperative chemoradiation with cetuximab in locally advanced rectal cancer: a pooled analysis of 2 phase II trials. International Journal of Radiation Oncology, Biology, Physics 2012, http://dx.doi.org/10.1016/j.ijrobp.2012.03.048.

[141] Gaedcke J, Grade M, Jung K, et al. KRAS and BRAF mutations in patients with rectal cancer treated with preoperative chemoradiotherapy. Radiotherapy and Oncology 2010;94:76-81.

[142] Grimminger PP, Danenberg P, Dellas K, et al. Biomarkers for cetuximab-based neoadjuvant radiochemotherapy in locally advanced rectal cancer. Clinical Cancer Research 2011;17:3469-77.

[143] Bengala C, Bettelli S, Bertolini F, et al. Prognostic role of EGFR gene copy number and KRAS mutation in patients with locally advanced rectal cancer treated with preoperative chemoradiotherapy. British Journal of Cancer 2010;103:1019-24.

[144] Grade M, Gaedcke J, Wangsa D, et al. Chromosomal copy number changes of locally advanced rectal cancers treated with preoperative chemoradiotherapy. Cancer Genetics and Cytogenetics 2009;193:19-28.

[145] Chen Z, Liu Z, Li W, et al. Chromosomal copy number alterations are associated with tumor response to chemoradiation in locally advanced rectal cancer. Genes, Chromosomes and Cancer 2011;50: 689-99.

[146] Nishioka M, Shimada M, Kurita N, et al. Gene expression profile can predict pathological response to preoperative chemoradiotherapy in rectal cancer. Cancer Genomics Proteomics 2011;8:87-92.

[147] Ghadimi BM, Grade M, Difilippantonio MJ, et al. Effectiveness of gene expression profiling for response prediction of rectal adenocarcinomas to preoperative chemoradiotherapy. Journal of Clinical Oncology 2005;23:1826-38.

[148] Rimkus C, Friederichs J, Boulesteix AL, et al. Microarray-based prediction of tumor response to neoadjuvant radiochemotherapy of patients with locally advanced rectal cancer. Clinical Gastroenterology and Hepatology 2008;6:53-61.

[149] Kim IJ, Lim SB, Kang HC, et al. Microarray gene expression profiling for predicting complete response to preoperative chemoradiotherapy in patients with advanced rectal cancer. Diseases of the Colon and Rectum 2007;50:1342-53.

[150] Brettingham-Moore KH, Duong CP, Greenawalt DM, et al. Pretreatment transcriptional profiling for predicting response to neoadjuvant chemoradiotherapy in rectal adenocarcinoma. Clinical Cancer Research 2011;17:3039-47.

[151] Watanabe T, Komuro Y, Kiyomatsu T, et al. Prediction of sensitivity of rectal cancer cells in response to preoperative radiotherapy by DNA microarray analysis of gene expression profiles. Cancer Research 2006;66:3370-4.

[152] Allal AS, Kahne T, Reverdin AK, Lippert H, Schlegel W, Reymond MA. Radioresistance-related proteins in rectal cancer. Proteomics 2004;4:2261-9.

[153] Smith FM, Gallagher WM, Fox E, et al. Combination of SELDITOF-MS and data mining provides early-stage response prediction for rectal tumors undergoing multimodal neoadjuvant therapy. Annals of Surgery 2007;245:259-66.

\section{Biographies}

Francesco Torino received his MD cum laude in 1989 from the Catholic University of Rome, Italy. He specialized cum laude in Internal Medicine, Catholic University of Rome 
in 1994 and in Medical Oncology, Tor Vergata University of Rome in 2002. He was a medical oncologist at Health District "Roma-H" in 2001 and at "San Filippo Neri" Hospital of Rome in 2003. From 2010 till date, he has been working as an Assistant Professor of Medical Oncology, Department of Systems Medicine - Chair of Medical Oncology, Tor Vergata University of Rome and also as an Assistant Professor of Medical Oncology at the Post-graduate School of Medical Oncology, Obstetrics and Gynecology, and Urology of Tor Vergata University of Rome. Doctor Torino is the author/coauthor of more than 30 papers published in peerreviewed international journals and of 10 book chapters. His current areas of research include endocrine treatment-related toxicity of targeted and cytotoxic agents, evaluation of new predictive factors of resistance in colorectal cancer and the clinical utility of circulating tumor cells in colorectal cancer.

Roberta Sarmiento obtained her degree in Medicine and surgery at the University of Rome, La Sapienza, in 1997, cum laude, then she specialized in Oncology, at the University of Rome, La Sapienza, in 2001, cum laude. She spent her last year of fellowship in the United States, from January 2001 to March 2002, at the Brown University of Providence, RI, attending the laboratory of Clinical Pharmacology directed by Professor Paul Calabresi, working on tissue cultures. In 2004 she was appointed as assistant oncologist at the Division of Oncology of the Health District of Siena, then she moved to Rome in 2005, as oncologist at the Division of Oncology of the Azienda Ospedaliera "San Filippi Neri", where she works up to now. Roberta Sarmiento is the author of more than 30 scientific publications and 5 book chapters.

Giampietro Gasparini obtained his degree in medicine and surgery at the University of Padua in 1980. Subsequently he specialized in oncology, clinical pharmacology and radiotherapy. He was a fellow at the "Istituto Nazionale per la Ricerca e la Cura dei Tumori" of Milan, assistant at the "Centro di Riferimento Oncologico" of Aviano and then vicedirector of the Division of Medical Oncology at the General Hospital of Vicenza. In 1997 Gasparini was appointed as the head and founder of the Oncology at the Azienda Ospedaliera "Bianchi-Melacrino-Morelli" in Reggio Calabria, and then as Director of the department of Oncology. Presently Gasparini is director of the Division of medical Oncology at the Azienda Ospedaliera "San Filippo Neri" and professor at the faculty of Medicine and Surgery-Specialty of Oncology University "Tor Vergata", Rome. Gasparini is the author of 300 publications in peer-reviewed journals and more than 350 abstracts at scientific conferences and meetings. The personal impact factor and the citation index up to June 2012 are 830 and 9800, respectively; $H$-index 44 . Finally, he serves as a member of the editorial board of 25 international journals; recipient of national awards and reviewer for several journals and scientific organizations. 